Article

\title{
Saving Water while Doing Business: Corporate Agenda-Setting and Water Sustainability
}

\author{
Laura Kemper ${ }^{1, *}$ and Lena Partzsch ${ }^{2}$ (D) \\ 1 Research Institute of Organic Agriculture (FiBL), Ackerstrasse 113, CH-5070 Frick, Switzerland \\ 2 University of Freiburg, Tennenbacher Str. 4, D-79106 Freiburg, Germany; lena.partzsch@ifp.uni-freiburg.de \\ * Correspondence: laura.kemper@fibl.org; Tel.: +41-77-520-0598
}

Received: 5 January 2019; Accepted: 7 February 2019; Published: 9 February 2019

check for

updates

\begin{abstract}
Organic and fair trade campaigns bring water sustainability onto public agendas, such as for example in the cotton/textile sector. Armedangels, a German company, advertises its t-shirts by arguing that their production requires only $1 / 10$ th of the water required in conventional production. This article studies the ambitions of such corporate agenda-setters. Methodologically, we develop a framework that contains six criteria and nine indicators, which allow us to code and assess the certification standards. In addition, we conducted semi-structured interviews, group discussions, and participatory observations in order to better understand whose agendas certification is promulgating. The criteria encompass the social and environmental dimensions of water sustainability. Our cases include Naturland (a private organic standard), the European Union (EU) Organic Regulation (a public organic standard), the Fairtrade Labeling Organization (FLO) (a fair trade initiative), and the Fair for Life (FFL) standard (an organic and fair trade standard). Our study also looks at the Better Cotton Initiative (BCI) and Cotton made in Africa (CmiA), which are two multi-stakeholder initiatives that operate on the conventional market in cooperation with non-governmental organizations (NGOs). The findings demonstrate that organic and fair trade companies rightly present themselves as water policy entrepreneurs. However, crucial aspects of water sustainability remain hidden. In particular, there is a cleavage between the environmental agendas of organic movements and NGOs that are represented in certification and the urgent social water problems in the Global South.
\end{abstract}

Keywords: cotton; certification; water sustainability; agenda setting; water governance

\section{Introduction}

Organic and fair trade campaigns bring water sustainability onto public agendas, for example, in the cotton/textile sector. In this sector, water is a key sustainability issue. Conventional cotton requires an estimated 3000 to $7000 \mathrm{~L}$ of water to produce one $\mathrm{kg}$ of cotton lint. While it is technically a drought-resistant crop, a lack of water can affect both yield and fiber quality [1]. Armedangels [2] advertises its $t$-shirts by arguing that their production requires only $1 / 10$ th of the water required in the conventional production (see Figure 1). The German textile company, which uses organic and fair trade certification, draws attention to cotton being one of the thirstiest agricultural products [2,3]. Companies such as Armedangels perform policy entrepreneurship that is usually associated with non-governmental organizations (NGOs) [4,5]. This article studies the ambitions of such corporate agenda-setters regarding water sustainability. We first identify which aspects of water governance certification initiatives highlight on the political agenda, and which aspects remain hidden. Based on these results, we ask whether certification serves to mobilize greater water sustainability and, in turn, if textile companies act as the water policy entrepreneurs they claim to be.

Certified cotton now accounts for approximately $10 \%$ of the global cotton production area [6]. There are a range of companies, such as Armedangels and Hess Natur, in Germany and elsewhere 
that exclusively sell textiles made of certified cotton. Voluntary certification illustrates that political agenda-setting increasingly happens in the market sphere. Businesses exercise hidden power through self-regulation and voluntary certification initiatives that allow non-state actors to actively set rules $[7,8]$. Other assessments of certification schemes touch on the question of water sustainability in the cotton/textiles industry $[9,10]$. However, as these studies evaluate a wide range of criteria, water sustainability is only a minor consideration without detailed criteria. By contrast, our article is the first to comprehensively and systematically study water sustainability in cotton certification and identify which aspects are not addressed by certification, and therefore left off the agenda. We developed an original framework that assesses water sustainability in detail, and can be more broadly applied to determine the extent to which certification schemes address or do not address the social and environmental dimensions of water sustainability [11]. This framework was originally developed to analyze the water sustainability of palm oil certification schemes (against the backdrop on debates about Normative Power Europe and the EU Renewable Energy Directive). We adapted it to the agricultural context of cotton cultivation. Except for this adaptation, both frameworks rely on the same combination of academic literature, including other water frameworks, and United Nations (UN) documents (see references below).

Our analysis compares water sustainability in six international standards that certify cotton. Several of these schemes are organic and/or fair trade schemes, which Raynolds et al. [12] (p. 154) mention are outstanding in terms of transparency and credibility. Naturland serves as an example of a private organic scheme. The European Union (EU) Ecolabel for textile products, which was introduced in 2014, serves as an example of a public organic standard. It is based on the EU Organic Regulation, which defines how organic agriculture, food, and textile products have to be produced. The Fairtrade Labeling Organization (FLO) International is an umbrella organization comprising 20 national initiatives, such as Transfair from Germany. Fair for Life (FFL) combines organic and fair trade certification. In addition, in the cotton sector, the Better Cotton Initiative (BCI) and Cotton made in Africa ( $\mathrm{CmiA}$ ) are examples of multi-stakeholder certification initiatives, which include NGOs (e.g., Oxfam, the Pesticide Action Network (PAN), and the World Wide Fund for Nature (WWF)) in decision making and standard setting (see Table 1).

In the following section, we first explain how certification serves agenda-setting and exercises hidden power, before introducing our six case studies in more detail. We then introduce our water sustainability framework with reference to cotton production in the third section. The framework contains six criteria and nine indicators, which allow us to code and assess the principles and criteria of the six certification schemes. In addition, we conducted semi-structured interviews and group discussions with stakeholders, as well as participatory observations. These data helped us to better understand whose agenda certification is promulgating. In particular, we used participatory observation at a Fair Trade Fair in Germany, and we visited a cotton project in Ethiopia, which was in the (successful) process of accreditation for EU organic certification. In Section 5, we outline the results of the content analysis.

Our findings demonstrate that through voluntary certification, organic and fair-trade companies indeed often exercise policy entrepreneurship, which is usually associated with NGOs. Private organic and fair trade standards without NGO participation are even more ambitious in mobilizing water sustainability, compared to the multi-stakeholder schemes with NGO participation. The mainstream (uncertified) market can learn from respective initiatives. However, while certification does address several crucial aspects of water sustainability, others remain hidden. In particular, our article shows that there is a cleavage between the environmental agendas represented in certification-by both NGOs and organic movements—and the most urgent social water problems on the ground.

\section{Hidden Power and Water Sustainability in Cotton Cultivation}

Hidden power refers to structural power that is not directly opposed by anyone. Bachrach and Baratz [13] wrote of "two faces of power", stressing that some issues do not make it onto the political 
agenda, and are dismissed before negotiations start. This is true for most environmental problems that are not openly discussed in parliaments. At the international level, problems associated with soil, forest, and water degradation receive far less attention than climate change $[14,15]$. Consumers in the Global North rely increasingly on certification initiatives to ensure that they are not unwillingly supporting such detrimental practices, including water overuse and degradation in cotton-producing countries. The basic idea is that if suppliers disclose information and certifiers guarantee compliance with specific standards, buyers voluntarily pay a higher price for their products. In turn, if buyers refrain from purchasing (non-)certified products, they may endanger the financial viability of the supplier-and of the certifier as well $[16,17]$.

Structural hidden power in the international arena also addresses coercion resulting from the capital mobility of transnational corporations. Threats to shift investments abroad are tacit, and can influence institutional politics in their favor [18]. More recently, studies have pointed out that businesses also exercise structural hidden power through private regulation and voluntary certification initiatives that allow business actors to actively set rules [7,8].

In addition to companies, NGOs are also increasingly engaged in regulating through certification networks. This collaborative approach has often replaced public "naming and shaming" campaigns and "demonizing" the mainstream market $[4,16]$. While NGOs participate in multi-stakeholder schemes in order to develop ethical market alternatives, their role continues to challenge and control the corporate sector. Hence, NGOs are assumed to be one of the main drivers behind environmental and social sustainability, also within certification schemes. Therefore, scholars attest to the legitimacy of third-party NGO-based certification schemes [12,19]. However, it is controversial whether NGO participation matters, or whether participating in multi-stakeholder certification only prevents them from publicly opposing corporate behavior and bringing environmental problems onto the political agenda $[20,21]$. While some NGOs—for example, WWF, Oxfam, and PAN—participate in multi-stakeholder certification, others-for example, Friends of the Earth (FoE) and many regional activist groups-consequently reject such non-state initiatives and demand public regulation instead [22].

In the cotton and textile sectors, the rise of certification initiatives has been fueled by increasingly globalized production and the declining public regulation of environmental and social conditions, especially internationally [21,23]. The phase-out of the Multi-Fiber Arrangement (MFA) and liberalized trade in apparel, paired with China's accession to the World Trade Organization (WTO) in 2001, has shifted the geography of apparel and textile production. Since 2005, textile trade has been subject to the normal WTO rules [24]. Çalişkan [25] demonstrated how the specific practices of market maintenance have changed over the last two decades. While UN strategies, such as the Development Pan African Cotton Road Map, have fallen short on reducing inequalities (especially for cotton farmers on the ground), research has so far very much focused on downstream textile certification $[4,17,20]$. Only a few scholars, such as Çalişkan and Sneyd $[25,26]$ have studied private governance efforts in cotton production.

Due to these changes in the cotton market, the environmental and social burdens associated with the cultivation of cotton, such as water overuse and pollution, have been disproportionately shifted to producing countries of the Global South [20,23]. In particular, cotton is one of the most important cash crops in water-scarce regions of sub-Saharan Africa, accounting for $15 \%$ of global cotton lint exports [27] (p. 83). The Food and Agriculture Organization (FAO) predicts global fertilizer use to exceed $201 \mathrm{Mt}$ by the end of 2020 [28] (p. 3). In sub-Saharan Africa alone, the increase in demand for synthetic fertilizer is expected to grow $11.2 \%$ and $7.3 \%$ annually for nitrogen-based fertilizer and phosphate-based fertilizer, respectively, between 2018-2020 [28] (p. 21). Along with the increase in pesticide and fertilizer consumption comes a variety of environmental implications, particularly water pollution from the two main ingredient nutrients: nitrogen and phosphorous. Even though $28 \%$ of all African lakes and reservoirs are subject to eutrophication [29], a large part of the population relies on untreated surface water, for example, $44 \%$ in the highest region of Ethiopia [30] (annex 6). 
While public authorities have regulated water resources (e.g., the Water Framework Directive in the EU), Western governments face challenges in facilitating the implementation of environmental and social norms outside their jurisdictions. Against this backdrop, non-state actors now take the lead and set their own agendas $[7,8]$. Consequently, power in the global political economy has been spread out, leaving non-state actors with considerable agenda-setting power also in water governance [14]. While some scholars interpreted the inclusion of more actors as a chance for change toward more water sustainability (e.g., [31,32]), others have emphasized the winners and losers resulting from these processes, i.e., some water issues are left off public agendas (e.g., $[7,21])$. The latter have warned that the "privatization of world politics" [33] (authors' translation) is not leading the way, but rather preventing stricter government rules for agriculture and other sectors. In addition, standards were demonstrated to be "trade weapons" that Western states and firms use to covertly maintain their dominance in global markets [24] (p. 5).

Kingdon's [5] multiple-stream framework explained why and how certain issues receive public attention in a "window of opportunity". According to him, policy entrepreneurs need to join information about problems (problem stream), solutions to these problems (policy stream), and politics (political stream). Similar to Kingdon [5], Baumgartner and Jones' [34] punctual equilibrium thesis described the policy cycle as characterized by long stable periods of incremental changes, interrupted by short moments of disruptive change. Significant change is only possible if policy entrepreneurs manage to modernize policy images and use policy arenas for this purpose. It stands to reason that with the increasing significance of non-state actors, such policy arenas also shift to the market and social spheres [35]. Therefore, in our analysis below, we examine whether certified companies, such as Armedangels, hold up to their promises and set the agenda for water sustainability. While their campaigns raise some issues, others continue to be hidden. In this vein, considering that public attention is limited, the campaigns might serve to further hide crucial water issues from policy agendas.

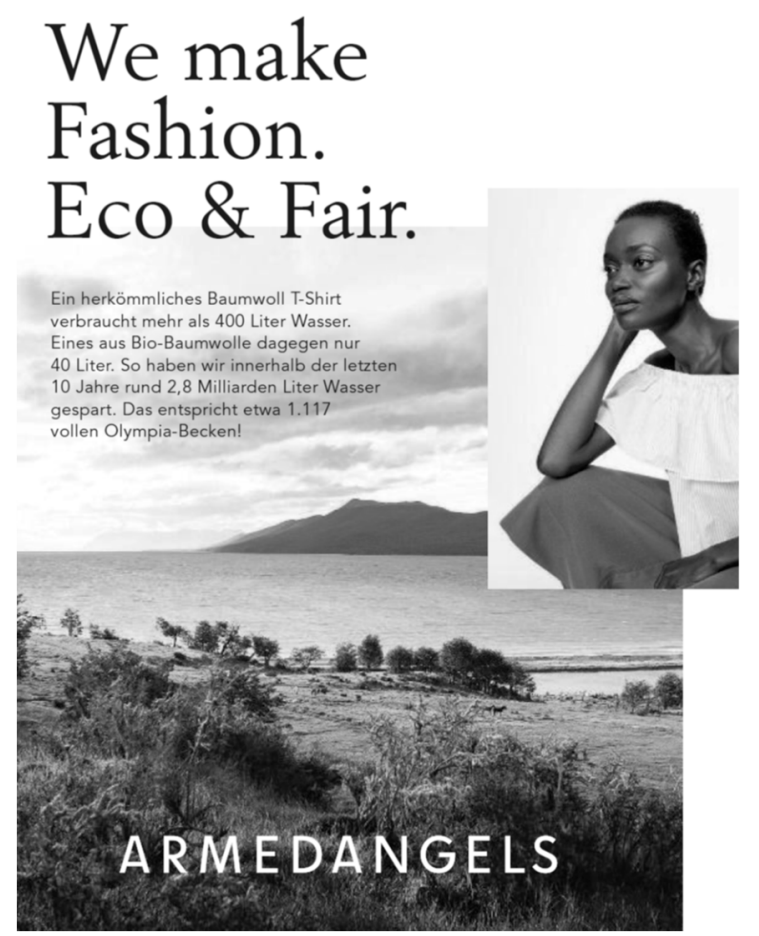

Figure 1. Armedangels advertisement (extract). Text of advertisement: "A conventional cotton t-shirt requires more than $400 \mathrm{~L}$ of water. An organic t-shirt, by comparison, only needs $40 \mathrm{~L}$. That is how we have been able to save approximately 2.8 billion liters of water over the last 10 years. That corresponds to about 1117 Olympic swimming pools." [2]. 


\section{Case Studies: Voluntary Cotton/Textiles Certification}

When promoting water sustainability issues and certification in cotton and textile production, companies such as Armedangels perform a political role, which is generally associated with NGOs. Therefore, we aim to explore whether certification can indeed improve water sustainability in cotton production. Organic and fair trade movements formed in the 1970s in clear opposition to the conventional systems. While organic movements used voluntary certification to resist the industrial expansion of agriculture [36], fair trade movements sought to rectify trade injustice and aimed to overcome the colonial division of labor between producers in the Global South and consumers in the Global North [37]. In 2015, more than 112,000 $t$ of cotton lint and 308,000 $t$ of seed cotton were certified organic. Organic cotton was produced on over 350,000 ha of land, representing $1 \%$ of the global cotton area. Fair trade cotton is grown on 45,000 ha worldwide, with an overall volume of almost $44,000 t$, representing $0.2 \%$ of cotton grown worldwide [6].

Naturland exemplifies an organic trademark, with close relations to the International Federation of Organic Agriculture Movement (IFOAM). Ten farmers founded the certification initiative close to Munich, Germany, in 1982. After first certifying only agricultural products in the region, Naturland started its international activities in 1986 and cotton/textile certification in 1999. Since 2010, Naturland has offered fair trade standards as a voluntary supplementary certification procedure; examination can be done simultaneously with the annual inspection to corroborate conformity with organic standards. However, for our evaluation below, we only considered the basic requirements to achieve Naturland organic certification. In 2017, over 38,000 farmers in 44 countries managed an area of some 320,000 ha, according to the Naturland standards [38,39].

After the EU Organic Regulation (EC 834/2007) established a unified organic label for food products in 2007, the European Commission also introduced the EU Ecolabel for textile products in 2014, which is based on the same production requirements as the organic food products (2014/350/EU). Although certification continues to be voluntary, these standards have taken the form of public law in the EU. This means that sovereign Westphalian authority is imposed on any farmer who wants to become certified as organic, even outside the EU territory, if the cotton or textile is later exported and sold as organic on the European market [40] (p. 22).

In the case of the Ethiopian cotton project that we visited in September 2017 (see Section 4), Pesticide Action Nexus Association (PAN) Ethiopia, a local NGO that collaborates with PAN United Kingdom (UK), is a UK charity tackling the problems caused by pesticides. In Arba Minch, PAN Ethiopia worked with 2000 cotton smallholders close to Arba Minch and helped them obtain EU organic certification [41]. The NGO received funding from the Food and Agriculture Organization (FAO), as well as the UK charities TRAID and the Sainsbury Family Charitable [42]. PAN Ethiopia told us that they had chosen EU Organic because it was the easiest organic standard for the smallholders to achieve. The farmers agreed, with the expectation that they would be able to export their cotton harvest to the EU and receive higher prices for their yield. They were not aware of other types of certification initiatives, for example, fair trade certification. However, despite the farmers' expectations, organic cotton farmers do not necessarily receive higher prices for their yield, and having an EU certification does not mean that European retailers directly purchase from respective producers [43]. The smallholders in Arba Minch had to continue selling their cotton to the local spinning plant for the conventional price.

Unlike organic branding, labeling products as 'fair trade' in the EU or elsewhere is not restricted by law. Only private brands and labels, such as the Fairtrade Labeling Organization (FLO) and Fair for Life (FFL), are registered trademarks, for which businesses can receive licenses. The creation of FLO as an international fair trade umbrella organization in 1997 made it possible to have an international fair trade label, which is recognized by consumers around the world [12,37]. Before, companies such as Cafédirect in the UK and GEPA (Gesellschaft zur Förderung der Partnerschaft mit der Dritten Welt) in Germany used to produce and label their own fair trade products. These companies do not offer any non-fair trade products; their brand name was identical to the label. By contrast, the FLO label 
can be used independently and makes it possible for conventional companies, such as Coop and Nestlé, to purchase select products under fair trade conditions and introduce fair trade segments into conventional supply chains, while they continue to sell non-fair trade products in parallel. For all fair trade purchases, companies have to fulfill a range of criteria. In particular, farmers get a guaranteed price, at least $10 \%$ above the world price (while non-certified farmers on the ground normally receive far less than the world price due to diverse intermediaries and their dependent position in the market) $[37,44]$.

Since several standards are either concerned with environmental or fair trade/social standards, many products carry both organic and fair trade labels. For example, $65 \%$ of fair trade seed cotton producers are also certified organic (in 2014-2015) [45] (p. 127). Armedangels is a FLO licensee, but also guarantees compliance with organic farming standards [46]. Fair for Life (FFL) combines organic and fair trade certification, and documents the entire supply chain, currently covering 600 operators and 140,000 small-scale producers, including four cotton/textile operators in six countries (in January 2018). The Swiss Bio Foundation created the international FFL scheme in 2006, and handed over ownership of the program to the ECOCERT Group in 2014. The program recognizes several other fair trade standards, including the FLO standards. Although a transition to organic farming is strongly encouraged, farmers do not need to be certified organic to apply for the certification [47].

The creation of uniform labels, such as EU Organic and FLO, made it possible for conventional companies to certify a share of their production following voluntary fair trade and organic standards. However, in addition, conventional companies created new cotton certification initiatives in cooperation with international NGOs. The Better Cotton Initiative (BCI) and Cotton made in Africa $(\mathrm{CmiA})$ are the most dominant schemes certifying cotton cultivation, based on the number of producers and volume of cotton certified. Producers who qualify for the CmiA certification are able to market their cotton as both BCI and CmiA [21,48].

Michael Otto, the owner of one of the world's largest e-commerce companies and a well-known German environmentalist, founded CmiA in 2005. Several NGOs, such as the German NABU (Naturschutzbund), WWF, and Welthungerhilfe, contributed to formulating the CmiA certification standard [49]. The CmiA initiative only certifies smallholders with one to three ha of land. In 2015, they certified more than 670,000 smallholders, who produced almost $342,000 \mathrm{t}$ of cotton lint on over 975,000 ha of land. CmiA-certified cotton accounts for approximately $3 \%$ of the global cotton area and $21 \%$ of the African cotton area [6] (p. 96). By contrast, BCI certification can be obtained for all farm sizes and operates globally. BCI was initiated in 2010 by a roundtable initiative led by the WWF, in conjunction other environmental NGOs (e.g., Oxfam and PAN UK). BCI works with more than 800,000 farmers and certifies over two Mt of cotton lint (in the 2015-2016 growing season), from over 2.2 million ha in 23 countries $(6.89 \%$ of global seed cotton production and $6.4 \%$ of the global cotton area) [6].

Naturland, the EU Organic Regulation, FLO, FFL, BCI, and CmiA serve as case studies to assess which aspects of water sustainability certification schemes pay attention to and which aspects remain hidden from public agendas. Other assessments of certification schemes touch on the question of water sustainability in the cotton/textiles industry, but in a very limited sense. For example, the Christliche Initiative Romero did an assessment called "Guide through the label labyrinth" (authors' translation), which looks at how various consumer labels address sustainability. In terms of water sustainability, the assessment only addresses water efficiency and wastewater [10]. Similarly, BSD Consulting and the web portal "Get changed", which promotes certified textiles, analyzed eight textile certification schemes with regard to the "protection of water resources", among other criteria. They found that CmiA, and two organic schemes (Global Organic Textile Standard (GOTS) and IVN Best), as well as Bluesign score best, whereas FLO and BCI scored lower. The assessment found that the Business Social Compliance Initiative (BSCI) and Fairware Foundation, two business schemes with a social/fair trade focus, do not consider water protection at all [9]. However, as these studies evaluate a wide range of criteria, water sustainability is only a minor consideration without detailed criteria. Therefore, in an 
earlier article, we developed a water sustainability framework that can be more broadly applied to determine the extent to which certification schemes address water sustainability (see also [11]). Hence, with this article, we expand our research on water sustainability in certification to another sector (while also referring to a different research debate and the topic of the Special Issue 'Attention and Water Governance: An Agenda-Setting Perspective' in WATER).

Table 1. Overview of certification schemes.

\begin{tabular}{|c|c|c|c|c|c|}
\hline $\begin{array}{l}\text { Certification } \\
\text { Scheme }\end{array}$ & $\begin{array}{c}\text { Stakeholder } \\
\text { Type }\end{array}$ & Initiator & Year Founded & $\begin{array}{l}\text { Certified } \\
\text { Products }\end{array}$ & Countries of Production \\
\hline $\begin{array}{l}\text { Better Cotton } \\
\text { Initiative } \\
\text { (BCI) }\end{array}$ & Multi-stakeholder & $\begin{array}{l}\text { World Wide Fund for } \\
\text { Nature (WWF) and } \\
\text { International Finance } \\
\text { Corporation (World } \\
\text { Bank) }\end{array}$ & 2010 & Cotton & $\begin{array}{c}\text { Australia, Brazil, China, } \\
\text { Cotton made in Africa } \\
\text { (CMiA) countries, India, } \\
\text { Israel, Mali, Mozambique, } \\
\text { Pakistan, Senegal, } \\
\text { Tajikistan, Turkey, United } \\
\text { States (USA) }\end{array}$ \\
\hline $\begin{array}{l}\text { Cotton made } \\
\text { in Africa } \\
(\mathrm{CmiA})\end{array}$ & Multi-stakeholder & $\begin{array}{c}\text { Aid by Trade } \\
\text { Foundation (owned by } \\
\text { businessperson Michael } \\
\text { Otto) }\end{array}$ & 2005 & Cotton & $\begin{array}{c}\text { Burkina Faso, Ethiopia, } \\
\text { Ivory Coast, Ghana, } \\
\text { Cameroon, Malawi, } \\
\text { Mozambique, Tanzania, } \\
\text { Uganda, Zambia, } \\
\text { Zimbabwe }\end{array}$ \\
\hline $\begin{array}{c}\text { European } \\
\text { Union (EU) } \\
\text { Organic Reg. }\end{array}$ & Public & EU & 2007 & $\begin{array}{l}\text { Organic } \\
\text { products }\end{array}$ & All \\
\hline $\begin{array}{c}\text { Fairtrade } \\
\text { Labeling } \\
\text { Organization } \\
\text { (FLO) }\end{array}$ & Fair trade & Solidaridad & 1997 & $\begin{array}{l}\text { Various, } \\
\text { including } \\
\text { cotton }\end{array}$ & All \\
\hline $\begin{array}{l}\text { Fair for Life } \\
\text { (FFL) }\end{array}$ & $\begin{array}{c}\text { Fair trade and } \\
\text { organic }\end{array}$ & $\begin{array}{l}\text { Swiss Bio Foundation } \\
\text { and IMO Group } \\
\text { (ECOCERT) }\end{array}$ & 2006 & $\begin{array}{l}\text { Various, } \\
\text { including } \\
\text { cotton }\end{array}$ & All \\
\hline Naturland & Fair trade & Farmer's association & 1982 & $\begin{array}{l}\text { Various, } \\
\text { including } \\
\text { textiles }\end{array}$ & All \\
\hline
\end{tabular}

Sources: Scheme websites.

\section{Methodology: Water Sustainability Framework for Assessing What Is (Not) on the Agenda}

Certification standards in the sustainable cotton sector specify acceptable production processes. Since water presents a fundamental sustainability issue for cotton production, we use a water sustainability framework to test the extent to which the public EU Organic Regulation, three early organic and/or fair trade schemes (FFL, FLO, and Naturland) as well as the two more recent multi-stakeholder schemes with NGOs' participation (BCI and $\mathrm{CmiA}$ ) address water sustainability. While other frameworks do exist to evaluate water sustainability, they are largely context and location-specific, and cannot be broadly applied. We reviewed a combination of academic literature (e.g., $[50,51])$ and UN documents (e.g., [52,53]) to develop a framework that can be more broadly applied. Based on this literature review, key water sustainability indicators were grouped together to form criteria in the water sustainability framework. All of the selected certification schemes meet the economic dimension of sustainability; otherwise, companies and producers would not use them. In contrast, cotton production presents several hidden social and environmental problems, which we address through our focus on water sustainability. The framework includes two criteria in the social dimension and four criteria within the environmental dimension. Each criterion and indicator is discussed and elaborated below. The first and second column of Table 2 provides an overview of the criteria and indicators. Our methodology is outlined in more detail in Appendix A. 


\subsection{Social Dimension}

The social dimension focuses on societal welfare, emphasizing access to education, services, and natural resources [54,55]. Previous assessments of cotton/textile certification have neglected this sustainability dimension in water governance [9,10]. It consists of two criteria: (1) community capacity and (2) access to water. First, community capacity refers to the abilities and resources that communities have. Those who are knowledgeable about water sustainability issues are more likely to act in a more sustainable way [56]. This can be in the form of formal education or simply skills and information, and thus can be largely mitigated by requiring basic training. Similarly, it is very difficult for producers without access to data on the status of water resource (availability, use, quality, risk, etc.) to ensure sustainability regarding water resources. By distributing information, accessing traditional knowledge, or collecting information from various stakeholders, many of these problems can be avoided. Therefore, we define two indicators to assess the extent to which community capacity is addressed: (a) knowledge and skills, as well as (b) access to information.

Second, while access to water is fundamental to human life, it is impeded by several factors, which, for cotton production, it can generally be classified into two categories. First, cotton production not only uses significant amounts of water, it also pollutes water sources, impeding access to the quantity and quality of water for community members to meet their basic needs $[57,58]$. Second, where water rights are not respected or enforced, they can be appropriated by other actors, and access to water can be impeded [59]. Therefore, schemes can address this by including criteria that protect quantity and the quality of community water resources as well as addressing water rights and how water disputes can be resolved. Therefore, we define the two indicators to assess the extent to which the schemes respect access to water resources: (a) the quantity and quality of water, and (b) rights to water.

The two criteria in the social dimension are, to a large extent, interconnected: where community capacity is lacking, poor agricultural practices can impact water resources, and conversely, where access to water is lacking, community capacity can be impeded due to a lack of resources [60].

\subsection{Environmental Dimension}

The environmental dimension of water sustainability emphasizes ecological integrity by understanding and preserving natural systems [56]. Although there are many factors that can affect this, they can generally be categorized into four groups, which we include as criteria. (1) Surface and groundwater availability: Although freshwater resources are renewable, mismanagement and overuse can lead to their depletion [61]. Therefore, it is critical that water withdrawals are brought in line with renewable levels of surface and groundwater, and that demands from various users are balanced [52]. (2) Water quality: If water is contaminated, the ecosystem, as well as its ability to provide ecosystem and water-related services, is inhibited [52]. (3) Water requirements for ecosystem health: Sufficient water to meet environmental water requirements is critical for ensuring ecological integrity [52]. Ensuring these requirements are met not only promotes healthy ecosystems, but also maintains water-related services [51], and plays a particularly important role in ensuring ecosystem capacity for future generations [53]. (4) Water-related disasters mitigation also plays an important role for water sustainability [52]. As a group, water-related disasters are largely driven by environmental factors, such as climate change, and represent $90 \%$ of all natural hazards [61]. Since droughts and floods are among the most prominent water-related disasters [1], they are focused on in this framework. The indicators for each criterion are outlined here.

Surface and groundwater availability is assessed, first, by water use and efficiency. Cotton often implements irrigation practices, which can deplete water sources [52]. Therefore, it is important that operations implement water management practices that are less water-intensive and ensure that there is no water waste or loss through poor agricultural practices or leakages [56] (p. 576). Finally, it is important to ensure that natural water availability is adequate in order to prevent over-pumping, which occurs when groundwater is extracted faster than it can naturally recharge, and can result in the permanent depletion of water sources $[52,54]$. Therefore, the two indicators for surface and 
groundwater availability are (a) water use and efficiency and (b) water availability. Both indicators are interrelated, as high water use and inefficiencies are less of a problem in water-abundant regions, while the most careful and efficient use might aggravate problems in water-scarce areas. Cotton cultivation might compete with water use for food production or even fundamental human needs in those latter areas.

Water quality is primarily compromised of contamination from human activities, including agricultural runoff. Agricultural practices can lead to contamination from pesticides, herbicides, or fertilizer use [52]. It is important that producers address chemical use and how to prevent both runoff and waste products from coming into contact with water. Therefore, one indicator is included: pollution from agricultural practices.

Water requirements for ecosystem health are important in order to maintain biodiversity and ecosystem services. Due to the complexity of aquatic ecosystems, it is difficult to determine all of the consequences that certain actions may have, both in the short and long-term [62]. Therefore, it is important that practices to enhance or maintain overall aquatic/riparian biodiversity and prevent adverse effects are put in place. Consequently, we include one indicator: biodiversity and ecosystem services.

Water-related natural disasters refer here to droughts and floods. While many regions in Africa have abundant water overall, it is generally characterized by high variability, resulting in droughts and floods [62]. Consequently, one indicator is included: drought/flood mitigation measures.

In order to determine the extent to which certified cotton production addresses specific aspects of water sustainability, while others remain hidden, we assessed the criteria of each of the six schemes against the water sustainability framework that is outlined above. Indicators that are robustly addressed by the scheme, without any loopholes or exceptions, were coded positively (green). Those that are weakly addressed (i.e., do not necessarily need to be implemented, contain obvious loopholes, or are only weakly connected to the indicator) were coded neutrally (yellow). Finally, indicators that are not at all addressed by the schemes were coded negatively (red). Table 2 presents a summary of all of the findings, and Appendix A lists them in detail.

In addition, we conducted 22 semi-structured interviews in person and by phone between June and September 2017. We interviewed and discussed with stakeholders involved in cotton certification (certifiers, producers, auditors, distributers, and NGOs) in a consumer country, Germany, and a producer country, Ethiopia. We participated in the annual Fair Trade Fair in Freiburg, Germany, on 19 May 2017. At the fair, we made observations about how retailers presented their certified textile products. We also engaged in several discussions and conducted two semi-structured interviews at the fair. Furthermore, we joined a group discussion with about 20 consumers, which followed a presentation by a fair trade textile producer.

In Ethiopia, we visited a project of cotton farmers who were in the accreditation process for the EU Organic Regulation certification close to Arba Minch in Southern Ethiopia between 4-6 September 2017 [41,42]. In the presence of a PAN Ethiopia representative, who coordinated the organic cotton project, we conducted two group discussions with cotton farmers about their perspectives on and experience with certification. Moreover, in Addis, we conducted interviews with people involved in certification and/or the textile industry in the cotton-exporting country. The interviews and discussions lasted between $30 \mathrm{~min}$ and three hours. Since the interviews contained sensitive economic and political information, the interviewees requested anonymity. While the interviews and group discussions were not conducted specifically for the purpose of this article, agenda setting emerged as a key theme in many interviews. Therefore, both the interviews and the participatory observations helped us better understand and interpret the results with regard to our guiding questions. Accordingly, the results are presented in the following section. 


\section{Results}

The results of the document analysis are presented visually in Table 2 and described in detail below. A detailed account of the analysis and results is available in Appendix B. All of the indicators mentioned in the text correspond to the indicators mentioned in the fourth column in Table 2.

\subsection{Social Dimension: Strongly Visible on the Fair Trade Agenda}

First, we assessed community capacity by looking at the degree to which the schemes respected the indicators (1a) knowledge and skills, and (1b) access to information. The first indicator is strongly addressed by the FFL and FLO, which both include training requirements for water-related issues. For example, the FLO stipulates that "[y]ou must provide training to the members of your organization on measures to use water efficiently" [63] (p. 16). Our interviews with cotton farmers in Ethiopia revealed that only through the process of accreditation did they realize how harmful and dangerous pesticides are to their own health. While pesticides are easily accessible, they joked that after the training, they would not let their kids come close to them, even if they were being bad.

Indicator $1 \mathrm{a}$ is weakly addressed by $\mathrm{CmiA}$ and Naturland. CmiA includes a criteria that stipulates:

[f]armers receive training to improve their agricultural practices in cotton production and the Managing Entity provides sufficient evidence to demonstrate that training needs are identified [and] target groups are defined. Training is not conducted regularly but sporadically. Training content does not reflect improvements on respective local circumstances nor does field evidence demonstrate that most farmers understand the positive impact of the trained practices. [64] (p. 6)

However, CmiA only requires compliance with $50 \%$ of criteria, so this requirement may not always be met. Indicator $1 \mathrm{a}$ is not at all addressed by the BCI or the EU Organic Regulation.

Similarly, indicator $1 b$ is strongly addressed by FFL and the FLO. For example, among other criteria, FFL stipulated that producers gain technical and practical knowledge about a variety of issues, including irrigation practices, through training or the dissemination of good practices amongst producers [65]. CmiA includes criteria about disseminating information, but that is not specific to water sustainability issues, and therefore only weakly addresses the indicator. Naturland, BCI, and the EU Organic Regulation do not address the indicator at all.

Second, we used indicators (2a) quantity and quality of water and (2b) rights to water to assess access to water. While indictor 2a is strongly addressed by the BCI and FFL, it is weakly addressed by the FLO and Naturland, and not at all addressed by CmiA and the EU Organic Regulation. For example, whereas the BCI requires that "[a]ccess to potable and washing water is provided" and "water extraction needs to take into account other users of the water resource" [66] (pp. 33 and 15), the FLO and Naturland only require that drinking water be provided for workers, but does not take into account the water needs of the surrounding communities.

Indicator $2 b$ is only addressed by two (business) schemes: FFL and Naturland, albeit strongly. For example, Naturland stipulates that "[a] product created under conditions violating basic human rights, under gross violation of social justice or infringing indigenous land and water rights cannot be traded as a product certified by Naturland" [38] (p. 13).

Therefore, in the social dimension, we find a cleavage between socially-orientated fair trade schemes and primarily environmentally-orientated schemes. This is particularly true for community capacity, which is strongly addressed by the fair trade-oriented schemes, and weakly or not at all addressed by the more environmentally-oriented schemes. 


\subsection{Environmental Dimension: The Focus of the Organic and Multi-Stakeholder Schemes}

The first criterion in the environmental dimension, surface and groundwater availability, was assessed according to two indicators: (3a) water use and efficiency, and (3b) water availability. Indicator 3a is strongly addressed by all of the schemes except the EU Organic Regulation. While CmiA does so by prohibiting irrigation, the FLO requires water efficiency training, and the BCI and FFL require that water usage is optimized and water waste eliminated. It is important to note that $\mathrm{CmiA}$ only works with smallholders who seldom have irrigation capacity. Therefore, they decided to prohibit irrigation, as they knew that their certified farmers would fulfill it per se. The Ethiopian cotton farmers we visited, who were in the process of being accredited under the EU Organic certification, had not even thought about irrigation facilities (and were, in this sense, going beyond the requirements of the EU Organic Regulation, which allows for irrigation).

Similarly, indicator $3 \mathrm{~b}$ is strongly addressed by all of the schemes except FFL, which weakly addresses it, and the EU Organic Regulation, which does not at all address it. The FFL criteria stipulates that "[t]he operation knows at least roughly the source and quantity of all the surface and ground water directly and/or indirectly used", but does not require any action to be taken in case of water scarcity [65] (p. 42).

Companies using certified cotton emphasize aspects of water use and efficiency in their advertisement campaigns. For example, as mentioned above, Armedangels highlights that the production of their $\mathrm{t}$-shirts requires considerably less water compared to non-certified production (see Figure 1) [2]. In a promotional video titled "Behind the fields: why we use organic fair trade cotton", the company called cotton "a water waster" and stated: "It takes $2120 \mathrm{~L}$ of water to produce one kg of cotton. That's more than 440 L for just one t-shirt" [67] (min. 0:30), and "Organic cotton farming needs 91\% less groundwater" [67] (min. 2:19). Similarly, on the CmiA website, they stated that they use $2100 \mathrm{~L}$ less water than the global average to produce one $\mathrm{kg}$ of cotton fiber [64]. However, these statements only concern indicator $3 a$, while there is no reference to indicator $3 b$, water availability.

Next, we assessed water quality through indicator (4a): pollution from agricultural practices, which is strongly addressed by all three organic and/or fair trade schemes (FFL, FLO, and Naturland) and the EU Organic Regulation. They do so by regulating how agricultural chemicals can be used and by addressing the runoff of these agricultural products to prevent water contamination. This can also have significant impacts on indicator (2a) quantity and the quality of water and (2b) rights to water. In Arba Minch, farmers mentioned that health problems disappeared after conversion to organic farming and the elimination of pesticides. The indicator is weakly addressed by the two multi-stakeholder schemes (BCI and $\mathrm{CmiA}$ ).

With regard to water pollution from agricultural practices, Armedangels emphasized the advantages of organic agriculture in an illustrative comparison to non-certified cotton cultivation: "Fifty-one grams of poison is sprayed on the fields to produce cotton for just one t-shirt. One t-shirt weighs $124 \mathrm{~g}(\ldots)$. We only use 100\% certified organic cotton. No toxic chemicals are used" [67] (min. 0:14, 2:43). However, this statement does not necessarily take into account the situation on the ground in the particular region. While pesticides and synthetic fertilizers are portrayed in a one-sided way ("poison"), there are situations (e.g., pest outbreak) in which individual farmers risk losing their whole harvest if they do not use pesticides. In such situations, the Arba Minch farmers admitted that they would use pesticides, even if it meant losing their organic certification. This means that even with strict pesticide and synthetic fertilizer standards, the schemes may not always be able to prevent such water pollution. 
The third criterion in the environmental dimension, water requirements for ecosystem health, was measured using indicator (5a) biodiversity and ecosystem services. The indicator is strongly addressed by the BCI, FFL, and FLO. For example, the BCI stipulates that "[p]ractices are adopted that enhance biodiversity on and surrounding the farm ... The protection of riparian land-the land surrounding water bodies-is particularly important, as it is often the most fertile and productive part of the landscape" [66] (p. 21). The indicator is only weakly addressed by the EU Organic Regulation, and Naturland, which address biodiversity in general, but fail to do so for riparian or aquatic areas specifically. In Arba Minch, farmers reported a return of birds after they had stopped spraying pesticides. The indicator is not at all addressed by CmiA.

Finally, water-related disaster mitigation, the fourth criterion in the environmental dimension, was assessed according to one indicator: (6a) drought/flood mitigation measures. Naturland is the only scheme to address this indicator, albeit weakly. They require that "farms draw up a water management plan, which comprises records and analysis of consumption, analysis of possible risks in conjunction with water use, and a plan of action for the reduction or prevention of these risks". However, this is only required in areas with scarce water resources [38] (p. 17).

In sum, the results demonstrate that the organic and/or fair trade schemes-FFL, FLO and Naturland-most strongly address water sustainability. As Table 2 highlighted, FFL strongly addresses seven of the indicators, and is therefore by far the most ambitious scheme in our analysis. The organic and/or fair trade schemes are followed by the multi-stakeholder schemes with NGO participation: BCI and CmiA. Although the BCI robustly addresses the same number of indicators as Naturland, they also fail to address several indicators at all. Therefore, Naturland still addresses water sustainability more comprehensively than the BCI. Finally, by addressing only two indicators, the public scheme-the EU Organic Regulation—is by far the weakest scheme in terms of water sustainability.

Table 2. Water sustainability in six cotton certification schemes. NL: Naturland.

\begin{tabular}{|c|c|c|c|c|c|c|c|c|c|}
\hline & & riteria & Indicators & FFL & FLO & NL & BCI & CmiA & EU \\
\hline \multirow{4}{*}{ Social } & \multirow[t]{2}{*}{1} & \multirow{2}{*}{$\begin{array}{l}\text { Community } \\
\text { capacity }\end{array}$} & $\begin{array}{l}\text { (a) Knowledge and } \\
\text { skills }\end{array}$ & & & & & & \\
\hline & & & $\begin{array}{l}\text { (b) Access to } \\
\text { information }\end{array}$ & & & & & & \\
\hline & \multirow[t]{2}{*}{2} & \multirow{2}{*}{$\begin{array}{l}\text { Access to } \\
\text { water }\end{array}$} & $\begin{array}{l}\text { (a) Quantity and } \\
\text { quality of water }\end{array}$ & & & & & & \\
\hline & & & (b) Rights to water & & & & & & \\
\hline \multirow{5}{*}{ Environmental } & \multirow[t]{2}{*}{3} & \multirow{2}{*}{$\begin{array}{l}\text { Surface and } \\
\text { groundwater } \\
\text { availability }\end{array}$} & $\begin{array}{l}\text { (a) Water use and } \\
\text { efficiency }\end{array}$ & & & & & & \\
\hline & & & (b) Water availability & & & & & & \\
\hline & 4 & Water quality & $\begin{array}{l}\text { (a) Pollution from } \\
\text { agricultural practices }\end{array}$ & & & & & & \\
\hline & 5 & $\begin{array}{c}\text { Water } \\
\text { requirements } \\
\text { for ecosystem } \\
\text { health } \\
\end{array}$ & $\begin{array}{l}\text { (a) Biodiversity and } \\
\text { ecosystem services }\end{array}$ & & & & & & \\
\hline & 6 & $\begin{array}{c}\text { Water-related } \\
\text { disaster } \\
\text { mitigation }\end{array}$ & $\begin{array}{l}\text { (a) Drought/flood } \\
\text { mitigation measures }\end{array}$ & & & & & & \\
\hline
\end{tabular}

Certification schemes are presented in order from most robust to least robust. The table is organized from most to least robust schemes, and depicts the extent to which each of the schemes respect the water sustainability criteria, using the following classifications: Indicator is clearly and robustly addressed by the certification scheme.

Indicator is addressed by the certification scheme, but criteria lack strength or specificity. Indicator is not at all addressed by the certification scheme.

\section{Discussion and Conclusions}

Certification initiatives allow businesses to exercise hidden power by setting agendas and actively formulating rules $[7,8]$. We compared organic and fair trade initiatives with more recent multi-stakeholder schemes and the EU public organic standard. The water sustainability framework 
served to identify the aspects of water governance that certification initiatives draw attention to, and which aspects are ignored. Our findings demonstrate, first, that the schemes have different aspects of water governance on their agendas. While the standards that evolved from early fair trade movements draw attention to social aspects of water governance (FLO and FFL), standards, which are either linked to organic movements or include NGOs in standard setting, focus on environmental sustainability (BCI, CmiA, EU Organic, and Naturland). On the one hand, this means that certification serves to mobilize toward greater water sustainability. On the other hand, in each scheme there are issues that remain hidden from the agenda.

The environmental issues brought forward by the majority of the certification schemes reflect the agendas of movements and NGOs in the Global North. In the Ethiopian cotton project, which we visited, the farmers participated in the accreditation process because they expected higher prices from exporting their cotton harvest to the EU. They prioritized their social well-being over aspects of environmental sustainability. For example, most focused on the health benefits associated with eliminating pesticide use, rather than environmental impacts. Therefore, in this case, the FLO and FFL, which highlight the social dimension, may have better served the farmers' interests.

By contrast, while the EU Organic Regulation, under which the smallholders in Arba Minch are certified, may indirectly address some of the social issues related to its environmental criteria, it does not directly target social water sustainability. As PAN Ethiopia pointed out, our analysis demonstrates that the EU Organic Regulation is the easiest standard to fulfill. However, it is also easy to fulfill because it does not address the social water issues, such as basic knowledge about water issues and basic rights to water, which are lacking in many communities in Arba Minch. Many communities lack basic knowledge about water issues, and often lack basic rights to water. The scheme was chosen by PAN Ethiopia, which received public and private funding from international institutions (FAO and UK charities) for this project. Hence, an environmental NGO set the agenda together with international donors in favor of environmental water sustainability, instead of considering the priorities of participating smallholders on the ground.

Scholars have emphasized the risks and opportunities of private certification $[7,21,24,33]$. We found that certification according to the EU Organic Regulation manifests the international agenda-setting of environmental sustainability, while social aspects of water sustainability remain hidden. Moreover, the farmers' motivation behind certification suggests that such standards can be used as "trade weapons" [24] (p. 5), as accreditation is considered a precondition to accessing the European market. However, without an organic buyer near Arba Minch, smallholders had to sell their certified cotton on the conventional market. Therefore, with technical and financial support from external donors (such as in Arba Minch), the high labor costs and price caps associated with certification projects can prevent farmers, in Ethiopia and elsewhere, from producing cotton organically [43] (p. 25).

NGOs, such as PAN, play a crucial role in cotton certification. As outlined above, the NGOs' role continues to challenge and control the corporate sector within certification schemes [19]. In addition, as with the Ethiopian project, they are crucial in acquiring funding to obtain certification on the ground. However, non-state organic and fair trade standards without participation by NGOs in standard setting are more ambitious with regard to water sustainability (FFL, FLO, and Naturland), compared to multi-stakeholder schemes with NGO members (BCI and CmiA). This finding allows us to draw two conclusions. First, certification prevents NGOs from publicly opposing harmful cotton business. NGOs that 'partner' with businesses are restricted in their possibilities of publicly shaming companies. Otherwise, they risk their collaboration $[19,21]$. At the same time, certification does not allow NGOs to assert ambitious agendas inside the certification initiatives. This means that collaboration does not change the companies' practices to the effect advocated by the NGOs. 
Second, our findings suggest that organic and fair trade companies, such as Armedangels, rightly present themselves as water policy entrepreneurs. They indeed take a political role that is normally associated with NGOs. While many NGOs involved in cotton certification refrain from publicly 'naming and shaming' harmful agricultural practices associated with the cotton industry, advertising campaigns by organic and fair trade companies do. However, as outlined above, certified companies only bring some aspects of water sustainability forward, and they hardly consider the specific circumstances on the ground. While FLO and Naturland, which most obviously emerged from activist movements, score similarly, the former focuses on fair trade, and the latter focuses on environmental water issues. Therefore, single projects are likely to continue shifting the environmental and social burden, especially if water-intense cotton replaces agriculture that is adapted to local conditions. The most water-efficient cotton cultivation techniques will not be sustainable in water-scarce areas. In this vein, instead of buying certified textiles, consumers may protect water resources more efficiently by, for example, upcycling their clothes. Another alternative is 'clothing swap' parties where people trade or exchange their secondhand clothes instead of buying new ones.

Certification projects need to replace more environmentally and socially harmful practices in order to be considered effectively contributing to greater sustainability. Manifesting the status quo, for example, by prohibiting irrigation where farmers do not have respective facilities anyway, does not lead to improved water situations on the ground. In such cases, cotton certification initiatives only prevent us from setting agendas with more fundamental agricultural and trade reforms (for example, replacing cotton in the Global North by raw materials grown locally such as flax/linen and lyocell/tencel).

Voluntary certification and labeling initiatives are increasingly seen as viable mechanisms for regulating sustainability in cotton/textiles, as well as other commodity areas. They are often praised as the most viable solution to fill the regulatory gap created by increasing globalization and the declining state regulation of social and environmental relations. However, the majority of cotton agriculture is not certified (more than $80 \%$ according to BCI [48]). Fair trade and organic certification covers only a niche market. While multi-stakeholder initiatives are on the rise, organic cotton production is declining slightly [43] (p. 5). Taking into account the social agendas of smallholder farmers may significantly improve the outreach and acceptance of certification schemes on the ground. While FFL already combines organic and fair trade standards, many companies such as Armendangels use both certification types in parallel (for example, the EU Textile and FLO labels). Optimistically, we may argue that organic and fair trade companies that rightly claim to be policy entrepreneurs are preparing the ground for more fundamental transitions to water sustainability. Pessimistically, we may admit that such groups have so far failed to direct sufficient attention toward water governance. By advertising limited solutions, companies such as Armedangels, and NGOs such as PAN, may have chosen the wrong strategies. The increasing consumer demand for ethical products alone does not protect water resources in exporting countries.

Author Contributions: Conceptualization, L.K. and L.P.; Methodology, L.K. and L.P.; Software, L.K.; Validation, L.K. and L.P.; Formal Analysis, L.K. and L.P.; Investigation, L.K. and L.P.; Resources, L.K. and L.P.; Data Curation, L.K.; Writing-Original Draft Preparation, L.K. and L.P.; Writing-Review \& Editing, L.K. and L.P.; Visualization, L.K. and L.P.; Supervision, L.P.; Project Administration, L.K. and L.P.; Funding Acquisition, L.P., please turn to the CRediT taxonomy for the term explanation. Authorship must be limited to those who have contributed substantially to the work reported.

Funding: This work was supported by the German Federal Ministry of Research and Education (project no. 031B0235A). The article processing charge was funded by the German Research Foundation (DFG) and the University of Freiburg in the funding programme Open Access Publishing.

Conflicts of Interest: The authors declare no conflict of interest. The funders had no role in the design of the study; in the collection, analyses, or interpretation of data; in the writing of the manuscript, and in the decision to publish the results. 


\section{Appendix A}

Table A1. Coding guide for Water Sustainability Framework. (Yellow: where no yellow requirements are indicated, the following apply: Criteria are not mandatory or do not require action; Green criteria are met, but not specific to water; Red: no requirements).

\begin{tabular}{|c|c|c|c|}
\hline Criteria & & Indicators & Requirements \\
\hline \multirow{4}{*}{1} & \multirow{4}{*}{ Community capacity } & & $\begin{array}{l}\text { Green: } \\
\text { - Must have specific training requirements for at least two water sustainability issues, OR } \\
\text { - One requirement directly related to water and at least } 2 \text { indirectly related }\end{array}$ \\
\hline & & (a) Knowledge and skills & Yellow: \\
\hline & & & $\begin{array}{l}\text { - Must have at least } 2 \text { training requirements for issues that likely influence water sustainability (i.e., } \\
\text { pesticide/fertilizer use or } \ldots \text { ), OR } \\
\text { - One training requirement specific to water }\end{array}$ \\
\hline & & (b) Access to information & $\begin{array}{l}\text { Green: Must include at least one requirement specific to distributing information or accessing traditional } \\
\text { knowledge that is specific to water AND at least one requirement about collecting information from other } \\
\text { stakeholders. Water management plans are one way to do this. } \\
\text { Yellow: Refers to the above requirements, but not specific to water (at least } 2 \text { issues) }\end{array}$ \\
\hline \multirow[b]{2}{*}{2} & \multirow[b]{2}{*}{ Access to water } & (a) Quantity and quality of water & $\begin{array}{l}\text { Green: must address drinking water access for both workers and community members. } \\
\text { Yellow: Addresses one or the other }\end{array}$ \\
\hline & & (b) Rights to water & $\begin{array}{l}\text { Green: Refers to legal tenure rights, specifically addressing water, or requires that land/water disputes } \\
\text { between traditional holders must be addressed } \\
\text { Yellow: Refers to land rights, but not water rights }\end{array}$ \\
\hline \multirow[t]{2}{*}{3} & \multirow[t]{2}{*}{$\begin{array}{l}\text { Surface and groundwater } \\
\text { availability }\end{array}$} & (a) Water use and efficiency & $\begin{array}{l}\text { Green: } \\
\text { - Rain-fed, OR limits amount of water that can be used, AND } \\
\text { - Rain-fed, OR water management practices that eliminate water waste } \\
\text { Yellow: one or the other }\end{array}$ \\
\hline & & (b) Water availability & $\begin{array}{l}\text { Green: demonstrates awareness about surrounding water resources and avoids depleting them } \\
\text { Yellow: Demonstrates awareness, not necessarily action }\end{array}$ \\
\hline 4 & Water quality & (a) Runoff from agricultural practices & $\begin{array}{l}\text { Green: must address chemical use and runoff (e.g., buffer zones) } \\
\text { Yellow: strategies to reduce pesticide/fertilizer use + demonstrate awareness/understanding of } \\
\text { implications, but no action required }\end{array}$ \\
\hline 5 & $\begin{array}{l}\text { Water requirements for } \\
\text { ecosystem health }\end{array}$ & (a) Biodiversity and ecosystem services & $\begin{array}{l}\text { Green: practices to enhance or maintain aquatic/riparian biodiversity or ensure no adverse effects } \\
\text { Yellow: } \\
\text { - Awareness, but not action } \\
\text { - Protects biodiversity but does not specify water }\end{array}$ \\
\hline 6 & $\begin{array}{l}\text { Water-related disaster } \\
\text { mitigation (droughts and } \\
\text { floods) }\end{array}$ & (a) Drought/flood mitigation measures & $\begin{array}{l}\text { Green: } \\
\text { - Specifically addresses drought OR flood mitigation measures } \\
\text { - Irrigation or water management plan that addresses risks of water-related disasters } \\
\text { Yellow: addresses general water risks, not specific to droughts or floods }\end{array}$ \\
\hline
\end{tabular}

* Any requirements that do not necessarily need to be met are considered yellow 


\section{Appendix B}

\section{Certification Scheme Analysis}

Schemes are listed in alphabetical order. The WSF column refers to the criteria and indicators in the water sustainability framework (WSF) outlined in Section 4 . The subsequent column lists the certification scheme's criteria that address the respective indicators in the WSF. Green indicates that the WSF indicator is robustly addressed by the scheme, yellow that it is addressed by the scheme, but lacks strength or specificity, and red indicates that the WSF indicator is not at all addressed by the scheme. In some cases, while the individual scheme indicators do not always address all aspects indicated in Annex 1, a combination of several criteria together strongly address the indicator.

Table A2. Better Cotton Initiative (BCI).

\begin{tabular}{|c|c|c|c|}
\hline WSF & & BCI Criteria & Justification \\
\hline \multirow{5}{*}{ 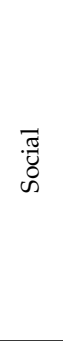 } & \multirow{2}{*}{ (1a) } & Capacity building principle & $\begin{array}{l}\text { Not addressed: Requires that some degree of training is } \\
\text { available; not specifically related to water }\end{array}$ \\
\hline & & & Not addressed \\
\hline & \multirow[t]{2}{*}{ (2a) } & $\begin{array}{l}\text { 2.2 Management practices are adopted to } \\
\text { ensure that water extraction does not cause } \\
\text { adverse effects on groundwater or water } \\
\text { bodies }\end{array}$ & Strongly addressed: addresses adverse effects on other users. \\
\hline & & $\begin{array}{l}6.2 \text { Access to potable and washing water is } \\
\text { provided. }\end{array}$ & Strongly addressed: ensures that drinking water is available \\
\hline & $(2 b)$ & & Not addressed \\
\hline \multirow{10}{*}{ 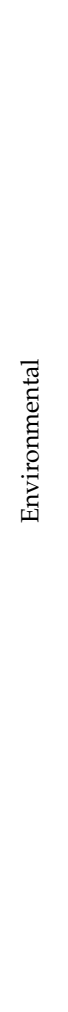 } & & $\begin{array}{l}\text { 2.1 Water management practices are } \\
\text { adopted that optimise water use }\end{array}$ & $\begin{array}{l}\text { Weakly addressed: Addresses optimising water use and } \\
\text { ensuring efficiency }\end{array}$ \\
\hline & (3a) & $\begin{array}{l}\text { 2.2 Management practices are adopted to } \\
\text { ensure that water extraction does not cause } \\
\text { adverse effects on groundwater or water } \\
\text { bodies. }\end{array}$ & Weakly addressed: Manages water extraction \\
\hline & $(3 b)$ & $\begin{array}{l}\text { 2.2 Management practices are adopted to } \\
\text { ensure that water extraction does not cause } \\
\text { adverse effects on groundwater or water } \\
\text { bodies }\end{array}$ & $\begin{array}{l}\text { Strongly addressed: demonstrates awareness about } \\
\text { surrounding water resources and avoids depleting them }\end{array}$ \\
\hline & \multirow{4}{*}{ (4a) } & $\begin{array}{l}\text { 1.7 Pesticide application equipment and } \\
\text { containers are stored, handled and cleaned } \\
\text { so as to avoid environmental harm and } \\
\text { human exposure. }\end{array}$ & $\begin{array}{l}\text { Weakly addressed: Should be done away from water bodies } \\
\text { to avoid runoff }\end{array}$ \\
\hline & & $\begin{array}{l}\text { 3.2 Nutrients are applied on the basis of } \\
\text { crop and soil needs. Timing, placement and } \\
\text { quantity applied are all optimised. }\end{array}$ & $\begin{array}{l}\text { Weakly addressed: Reduced fertilizer use and nutrient runoff } \\
\text { into water bodies; does not address pesticides }\end{array}$ \\
\hline & & $\begin{array}{l}\text { 3.3 Management practices are adopted that } \\
\text { minimise erosion, so that soil movement is } \\
\text { minimised and water courses, drinking } \\
\text { water sources and other bodies of water are } \\
\text { protected from farm run-off. }\end{array}$ & Weakly addressed: Only addresses run/off from erosion \\
\hline & & $\begin{array}{l}\text { 4.1 Practices are adopted that enhance } \\
\text { biodiversity on and surrounding the farm }\end{array}$ & $\begin{array}{l}\text { Weakly addressed: Suggests buffer zones to protect riparian } \\
\text { land }\end{array}$ \\
\hline & \multirow[t]{2}{*}{ (5a) } & $\begin{array}{l}\text { 2.2 Management practices are adopted to } \\
\text { ensure that water extraction does not cause } \\
\text { adverse effects on groundwater or water } \\
\text { bodies }\end{array}$ & $\begin{array}{l}\text { Weakly addressed: Needs to take into account the affects for } \\
\text { the aquatic ecosystem, no action stipulated }\end{array}$ \\
\hline & & $\begin{array}{l}\text { 4.1 Practices are adopted that enhance } \\
\text { biodiversity on and surrounding the farm }\end{array}$ & $\begin{array}{l}\text { Strongly addressed: Specifically addresses enhancing } \\
\text { biodiversity on riparian land }\end{array}$ \\
\hline & $(6 a)$ & & Not addressed \\
\hline
\end{tabular}


Table A3. Cotton made in African (CmiA).

\begin{tabular}{|c|c|c|}
\hline WSF & CmiA Criteria & Justification \\
\hline \multirow[b]{4}{*}{.ँّ } & $\begin{array}{l}\text { 3a. Farmers receive training to improve their agricultural practices in cotton production and the Managing } \\
\text { Entity provides sufficient evidence to demonstrate that training needs are identified, target groups are defined. } \\
\text { Training is not conducted regularly but sporadically. Training content does not reflect improvements on } \\
\text { respective local circumstances nor does field evidence demonstrate that most farmers understand the positive } \\
\text { impact of the trained practices. }\end{array}$ & $\begin{array}{l}\text { Weakly addressed: Addresses training; can happen } \\
\text { sporadically and not specific to water }\end{array}$ \\
\hline & $\begin{array}{l}\text { 4c. Regarding application of pesticides, the Managing Entity demonstrates awareness about the possibilities of } \\
\text { runoff or leaching of chemicals into streams or ground water and can prove that this is significant or } \\
\text { non-significant for the Unit. In the case of significance, however, the farmer is generally informed regarding the } \\
\text { dangers of leaching of chemicals into streams or ground water. There is no field evidence that farmers apply the } \\
\text { necessary techniques. }\end{array}$ & $\begin{array}{l}\text { Weakly addressed: Addresses water-related training; only } \\
50 \% \text { of criteria need to be complied with }\end{array}$ \\
\hline & $\begin{array}{l}\text { 4e. The Managing Entity provides sufficient evidence to demonstrate that more than } 80 \% \text { of farmers have been } \\
\text { trained in the principles of scouting and pest thresholds, which lead to the use of less pesticides. There is field } \\
\text { evidence that farmers understand the concept. }\end{array}$ & $\begin{array}{l}\text { Weakly addressed: Addresses water-related training; only } \\
50 \% \text { of criteria need to be complied with }\end{array}$ \\
\hline & $\begin{array}{l}\text { 5. The Managing Entity provides sufficient evidence to demonstrate that sporadical training is given on some of } \\
\text { the following issues: } \\
\text { - } \quad \text { early and appropriate land preparation } \\
\text { - } \quad \text { timely planting (and seed is available in time) } \\
\text { - } \quad \text { correct plant population and density } \\
\text { - } \quad \text { harvesting techniques relating to reducing contamination }\end{array}$ & $\begin{array}{l}\text { Weakly addressed: Addresses training; can happen } \\
\text { sporadically and not specific to water }\end{array}$ \\
\hline \multirow[t]{2}{*}{ (1b) } & $\begin{array}{l}\text { 4b. The Managing Entity provides information to farmers and affected employees about the risks and dangers } \\
\text { related to the storage of pesticides (including leaking containers), however, they have not received training in } \\
\text { appropriate safe storage measures such that access by children is prevented. (More than } 50 \% \text { of the farmers } \\
\text { visited store their chemicals correctly and prevent access by children.) }\end{array}$ & $\begin{array}{l}\text { Weakly addressed: Farmers have access to information, } \\
\text { but limited to pesticide risks; does not address traditional } \\
\text { knowledge or collecting information from other } \\
\text { stakeholders }\end{array}$ \\
\hline & $\begin{array}{l}\text { 4c. Regarding application of pesticides, the Managing Entity demonstrates awareness about the possibilities of } \\
\text { runoff or leaching of chemicals into streams or ground water and can prove that this is significant or } \\
\text { non-significant for the Unit. In the case of significance, however, the farmer is generally informed regarding the } \\
\text { dangers of leaching of chemicals into streams or ground water. There is no field evidence that farmers apply the } \\
\text { necessary techniques. }\end{array}$ & $\begin{array}{l}\text { Weakly addressed: Farmers have access to information, } \\
\text { but limited to pesticide risks; does not address traditional } \\
\text { knowledge or collecting information from other } \\
\text { stakeholders }\end{array}$ \\
\hline (2a) & & Not addressed \\
\hline (2b) & & Not addressed \\
\hline
\end{tabular}


Table A3. Cont.

\begin{tabular}{|c|c|c|c|}
\hline \multicolumn{2}{|c|}{ WSF } & CmiA Criteria & Justification \\
\hline \multirow{8}{*}{ 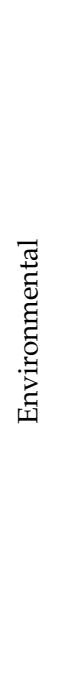 } & (3a) & Exclusion criterion 2: Cotton production under irrigation is excluded & Strongly addressed: Cotton must be rain-fed \\
\hline & $(3 b)$ & Exclusion criterion 2: Cotton production under irrigation is excluded & Strongly addressed: Cotton must be rain-fed \\
\hline & \multirow{4}{*}{ (4a) } & $\begin{array}{l}\text { 4a. The Managing Entity provides sufficient evidence to demonstrate an understanding about the impact of } \\
\text { pesticides used for cotton cultivation on environment, health and pest resistance but lack an integrated } \\
\text { improvement strategy }\end{array}$ & $\begin{array}{l}\text { Weakly addressed: Addresses understanding of chemical } \\
\text { use and impact, but no action required }\end{array}$ \\
\hline & & $\begin{array}{l}\text { 4c. Regarding application of pesticides, the Managing Entity demonstrates awareness about the possibilities of } \\
\text { runoff or leaching of chemicals into streams or ground water and can prove that this is significant or } \\
\text { non-significant for the Unit. In the case of significance, however, the farmer is generally informed regarding the } \\
\text { dangers of leaching of chemicals into streams or ground water. There is no field evidence that farmers apply the } \\
\text { necessary techniques. }\end{array}$ & $\begin{array}{l}\text { Weakly addressed: Addresses understanding of chemical } \\
\text { use and impact, but no action required }\end{array}$ \\
\hline & & $\begin{array}{l}\text { 4d. The Managing Entity provides sufficient evidence to demonstrate that the farmer is generally informed } \\
\text { regarding the dangers of re-using empty pesticide containers and how to dispose of these in a safe manner, but } \\
\text { there is no evidence that this is being applied. }\end{array}$ & $\begin{array}{l}\text { Weakly addressed: Addresses understanding of chemical } \\
\text { use and impact, but no action required }\end{array}$ \\
\hline & & $\begin{array}{l}\text { 4e. The Managing Entity provides sufficient evidence to demonstrate that more than } 80 \% \text { of farmers have been } \\
\text { trained in the principles of scouting and pest thresholds, which lead to the use of less pesticides. There is field } \\
\text { evidence that farmers understand the concept. }\end{array}$ & $\begin{array}{l}\text { Weakly addressed: Addresses understanding of chemical } \\
\text { use; not specific to water }\end{array}$ \\
\hline & (5a) & & Not addressed \\
\hline & $(6 a)$ & & Not addressed \\
\hline
\end{tabular}


Table A4. EU Organic Regulation.

\begin{tabular}{|c|c|c|c|}
\hline \multicolumn{2}{|c|}{ WSF } & EU Organic Regulation Criteria & Justification \\
\hline \multirow{4}{*}{ 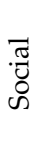 } & (1a) & & Not addressed \\
\hline & (1b) & & Not addressed \\
\hline & $(2 a)$ & & Not addressed \\
\hline & (2b) & & Not addressed \\
\hline \multirow{12}{*}{ 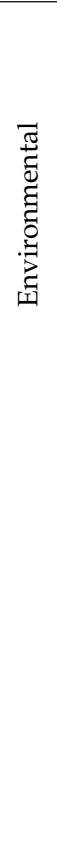 } & (3a) & & Not addressed \\
\hline & $(3 b)$ & & Not addressed \\
\hline & \multirow{7}{*}{$(4 a)$} & Article $4 \mathrm{~b}$ : restriction of the use of external inputs & $\begin{array}{l}\text { Strongly addressed: Addresses chemical uses-limited to } \\
\text { naturally-derived substances or low solubility mineral fertilizers (can be } \\
\text { better detected in water) }\end{array}$ \\
\hline & & $\begin{array}{l}\text { Article 12.1d: in addition, fertilisers and soil conditioners may only be used if they have been } \\
\text { authorised for use in organic production under Article } 16\end{array}$ & Strongly addressed: Addresses chemical uses \\
\hline & & Article 12.1e: mineral nitrogen fertilisers shall not be used & Strongly addressed: Addresses chemical uses \\
\hline & & $\begin{array}{l}\text { Article 12.1f: all plant production techniques used shall prevent or minimise any contribution to } \\
\text { the contamination of the environment }\end{array}$ & Strongly addressed: Not specific to water \\
\hline & & $\begin{array}{l}\text { Article } 12.1 \mathrm{~g} \text { : the prevention of damage caused by pests, diseases and weeds shall rely primarily } \\
\text { on the protection by natural enemies, the choice of species and varieties, crop rotation, } \\
\text { cultivation techniques and thermal processes }\end{array}$ & Strongly addressed: Addresses chemical uses \\
\hline & & $\begin{array}{l}\text { Article } 12.1 \mathrm{~h} \text { : in the case of an established threat to a crop, plant protection products may only be } \\
\text { used if they have been authorised for use in organic production under Article } 16\end{array}$ & Strongly addressed: Addresses chemical uses \\
\hline & & $\begin{array}{l}\text { Article } 12.1 \mathrm{j} \text { : products for cleaning and disinfection in plant production shall be used only if they } \\
\text { have been authorised for use in organic production under Article } 16\end{array}$ & Strongly addressed: Addresses chemical uses \\
\hline & \multirow{2}{*}{$(5 a)^{-}$} & $\begin{array}{l}\text { Article 5d: taking account of the local or regional ecological balance when taking production } \\
\text { decisions }\end{array}$ & Weakly addressed: Addresses ecosystem; not specific to water \\
\hline & & $\begin{array}{l}\text { Article 12.1f: all plant production techniques used shall prevent or minimise any contribution to } \\
\text { the contamination of the environment }\end{array}$ & Weakly addressed: Addresses ecosystem; not specific to water \\
\hline & (6a) & & Not addressed \\
\hline
\end{tabular}


Table A5. Fair for Life.

\begin{tabular}{|c|c|c|c|}
\hline \multicolumn{2}{|c|}{ WSF } & FFL Criteria & Justification \\
\hline \multirow{9}{*}{.ँّ } & \multirow{9}{*}{ (1a) } & SOC-34: A written Health and Safety policy exists, which is made known to the workers & $\begin{array}{l}\text { Weakly addressed: Health and safety training required; not specific to } \\
\text { water }\end{array}$ \\
\hline & & $\begin{array}{l}\text { SOC-37: Workers and management are informed and adequately trained on occupational health } \\
\text { and safety risk management (as appropriate for their duties). Trainings are regular and recorded, } \\
\text { and are repeated for all new or reassigned workers and management }\end{array}$ & Weakly addressed: Training provided, but not specific to water \\
\hline & & $\begin{array}{l}\text { SOC-38: Any workers carrying out high-risk activities (fork lift, chemical handling, and } \\
\text { hazardous machinery) have undergone adequate and, documented training, including in the } \\
\text { effective use of Personal Protection Equipments-PPE (see SOC-43). Training is performed at } \\
\text { least once a year, and renewed as required. }\end{array}$ & Weakly addressed: Training provided, but not specific to water \\
\hline & & $\begin{array}{l}\text { ENV-12: An Integrated Waste Management (clean operation, waste production, collection and } \\
\text { disposal is handled in an organized way including strategies both for appropriate waste } \\
\text { management and waste reduction) for continuous improvement is in place. This includes:-The } \\
\text { identification of the different types of wastes generated, and associated procedures for adequate } \\
\text { waste disposal and reduction-Adequate trainings of workers and Producers OR detailed } \\
\text { information about waste management and reduction }\end{array}$ & Weakly addressed: Training provided, but not specific to water \\
\hline & & $\begin{array}{l}\text { ENV-33: Technical and practical knowledge about the implementation of an Integrated Pest } \\
\text { Management (IPM) system is developed. This can be achieved through different ways, adapted } \\
\text { to the local context (see guidance). }\end{array}$ & Weakly addressed: Training provided, but not specific to water \\
\hline & & $\begin{array}{l}\text { ENV-38: Technical and practical knowledge about the implementation of soil conservation } \\
\text { techniques is developed (soil management, irrigation practices, groundcover, application of } \\
\text { fertilizers corresponding to the nutrients needs of the crop, building/maintaining soil fertility } \\
\text { and crop rotation (as applicable). This can be achieved through different ways, adapted to the } \\
\text { local context (see guidance). }\end{array}$ & $\begin{array}{l}\text { Strongly addressed: Addressed irrigation practices, which can be } \\
\text { improved through adequate training }\end{array}$ \\
\hline & & $\begin{array}{l}\text { ENV-44: The person responsible for the storage and the supervision of workers handling } \\
\text { pesticides has adequate and up-to-date training/knowledge in agrochemical handling. }\end{array}$ & Weakly addressed: Training provided, but not specific to water \\
\hline & & $\begin{array}{l}\text { LOC-7: The Operation supports the local social fabric through its engagement in environmental } \\
\text { projects (e.g., local recycling/composting programmes, training of local farmers in organic } \\
\text { production, renewable energy programmes, fight against urban sprawl, etc.). }\end{array}$ & $\begin{array}{l}\text { Weakly addressed: Training provided, but not specific to water; only a } \\
\text { bonus criterion and not required }\end{array}$ \\
\hline & & $\begin{array}{l}\text { LOC-8: The Operation is active in creating awareness, educating and training in Social } \\
\text { Responsibility (including environmental protection/sustainable use of natural resources). }\end{array}$ & $\begin{array}{l}\text { Weakly addressed: Training provided, but not specific to water; only a } \\
\text { bonus criterion and not required }\end{array}$ \\
\hline
\end{tabular}


Table A5. Cont.

\begin{tabular}{|c|c|c|}
\hline WSF & FFL Criteria & Justification \\
\hline \multirow[t]{4}{*}{ (1b) } & $\begin{array}{l}\text { ENV-38: Technical and practical knowledge about the implementation of soil conservation } \\
\text { techniques is developed (soil management, irrigation practices, groundcover, application of } \\
\text { fertilizers corresponding to the nutrients needs of the crop, building/maintaining soil fertility } \\
\text { and crop rotation (as applicable). This can be achieved through different ways, adapted to the } \\
\text { local context (see guidance). }\end{array}$ & $\begin{array}{l}\text { Strongly addressed: Addresses irrigation; can be done through } \\
\text { dissemination of good practices amongst producers (distributing } \\
\text { information) }\end{array}$ \\
\hline & $\begin{array}{l}\text { POL-18: The relevant groups (Workers, Producers, supervision and management staff, etc.) are } \\
\text { informed about the basic Fair Trade approach and possible implications, and at least of:--The } \\
\text { basic procedures for Fair Trade Fund administration;--The intent of the Fair Trade Development } \\
\text { Plan. }\end{array}$ & $\begin{array}{l}\text { Weakly addressed: Information is collected from other stakeholders; not } \\
\text { specific to water }\end{array}$ \\
\hline & SOC-48: Access to safe drinking water is provided, free of charge & Strongly addressed: Addresses drinking water access for workers \\
\hline & $\begin{array}{l}\text { SOC-69: The employer can demonstrate that the wages (including existing social benefits, } \\
\text { in-kind benefits and bonuses) paid to ALL workers for normal working hours are equal to or } \\
\text { above living wages (see guidance). Otherwise, the employer shall provide a plan to } \\
\text { progressively reach the living wage and apply this plan. A timeframe will be set depending on } \\
\text { the available resources and means at the employer level. If no benchmark is available and it } \\
\text { would be too complex to calculate the living wage, the employer shall prove that particularly } \\
\text { good, participatory and inclusive wages agreements have been made, and this is confirmed by } \\
\text { the workers. }\end{array}$ & $\begin{array}{l}\text { Strongly addressed: Addresses drinking water access for others: Living } \\
\text { wage is adequate to meet basic needs (including adequate drinking water) }\end{array}$ \\
\hline \multirow[t]{3}{*}{ (2a) } & $\begin{array}{l}\text { ENV-10: There are specific measures in place to ensure that waste water does not contaminate } \\
\text { drinking water sources }\end{array}$ & Strongly addressed: Addresses drinking water contamination \\
\hline & $\begin{array}{l}\text { ENV-57: The Operation has established buffer zones to prevent any negative environmental } \\
\text { impact from its activity on:-Protected areas-Water bodies and drinking water sources-Areas } \\
\text { of daily human activity-Other cultivated areas where no/less pesticides are used }\end{array}$ & Strongly addressed: Addresses drinking water contamination \\
\hline & $\begin{array}{l}\text { LOC-9: The Operation's overall activities and efforts in the local community are in line with } \\
\text { sustainable principles, and do not have a negative impact on local/indigenous communities, on } \\
\text { the environment or on local sustainable development (lobbying for weaker environmental } \\
\text { legislation, promotion of unsustainable practices, etc.). }\end{array}$ & $\begin{array}{l}\text { Weakly addressed: Addresses impacts on surrounding communities; not } \\
\text { specific to water }\end{array}$ \\
\hline$(2 b)$ & $\begin{array}{l}\text { LOC-1: The Operation holds valid, legal and undisputed land use and tenure rights (including } \\
\text { resource use rights such as water use, see guidance). If there are any disputes, they are handled } \\
\text { responsibly }\end{array}$ & Strongly addressed: Addresses land tenure and water rights \\
\hline
\end{tabular}


Table A5. Cont.

\begin{tabular}{|c|c|c|c|}
\hline \multicolumn{2}{|c|}{ WSF } & FFL Criteria & Justification \\
\hline \multirow{12}{*}{ 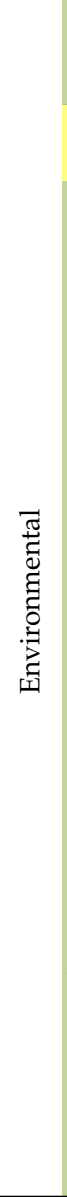 } & (3a) & $\begin{array}{l}\text { ENV-2: Adequate water use practices and rational use of water; no apparent waste of water, e.g., } \\
\text { through very inappropriate irrigation techniques, ineffective use in processing, or other loss of } \\
\text { water }\end{array}$ & $\begin{array}{l}\text { Strongly addressed: Addresses amount of water that can be used and } \\
\text { water waste }\end{array}$ \\
\hline & $(3 b)$ & $\begin{array}{l}\text { ENV-1: The Operation knows at least roughly the source and quantity of all surface and ground } \\
\text { water directly and/or indirectly used }\end{array}$ & $\begin{array}{l}\text { Weakly addressed: Demonstrates awareness of water resources; no action } \\
\text { required to maintain minimum levels }\end{array}$ \\
\hline & \multirow{10}{*}{$(4 a)$} & $\begin{array}{l}\text { ENV-8: Waste water (processing waste water, farm waste water) is treated in an appropriate } \\
\text { manner, with no substantial risk to environment or people. }\end{array}$ & $\begin{array}{l}\text { Strongly addressed: Addresses contaminations of surrounding } \\
\text { environment }\end{array}$ \\
\hline & & $\begin{array}{l}\text { ENV-9: When water is discharged into natural water bodies, the water discharged does not } \\
\text { degrade the biochemical and physical characteristics of the receiving water body, and does not } \\
\text { include organic or inorganic solids. Depth of analysis to ensure and monitor this may vary } \\
\text { according to size and potential risks of the operation (see guidance). }\end{array}$ & Strongly addressed: Addresses water pollution \\
\hline & & $\begin{array}{l}\text { ENV-10: There are specific measures in place to ensure that waste water does not contaminate } \\
\text { drinking water sources }\end{array}$ & Strongly addressed: Addresses water pollution \\
\hline & & $\begin{array}{l}\text { ENV-14: There are designated locked areas for the storage of hazardous waste, with adequate } \\
\text { measures in place to avoid pollution of water bodies (see guidance). }\end{array}$ & Strongly addressed: Addresses water pollution \\
\hline & & $\begin{array}{l}\text { ENV-37: Hand or mechanical weeding and mulching are used as a first practice to reduce weeds. } \\
\text { If herbicides are used, it is only done upon written justification and with proven efforts to } \\
\text { reduce/eliminate their application. }\end{array}$ & Strongly addressed: Limits use of chemicals \\
\hline & & ENV-54: Adequate pesticide application methods are practised. See details in Guidance text. & Strongly addressed: Regulates chemical use and addresses contamination \\
\hline & & $\begin{array}{l}\text { ENV-56: Aerial spraying is carried out only for fungicide application in exceptional cases (see } \\
\text { Guidance) }\end{array}$ & $\begin{array}{l}\text { Strongly addressed: Addresses water pollution: Spraying cannot be done } \\
\text { over water bodies }\end{array}$ \\
\hline & & $\begin{array}{l}\text { ENV-57: The Operation has established buffer zones to prevent any negative environmental } \\
\text { impact from its activity on:-Protected areas-Water bodies and drinking water sources-Areas } \\
\text { of daily human activity-Other cultivated areas where no/less pesticides are used }\end{array}$ & Strongly addressed: Addresses runoff (buffer zones) \\
\hline & & $\begin{array}{l}\text { ENV-16: The operation provides: an overview of the habitats and the existing flora and fauna (at } \\
\text { least vertebrates and for the ecosystem relevant insects) in the natural/semi natural areas of } \\
\text { special ecological value inside or adjacent to the operation }\end{array}$ & Weakly addressed: Stipulates an overview of situation; no action required \\
\hline & & $\begin{array}{l}\text { ENV-17: Based on the biodiversity diagnosis (ENV-16), the operation is able to } \\
\text { identify:- - threatened or endangered species of fauna and flora (see Guidance) and their habitats } \\
\text { inside or adjacent to the operation;- - the existing or potential threats to their conservation. }\end{array}$ & Weakly addressed: Stipulates identification; no action required \\
\hline
\end{tabular}


Table A5. Cont.

\begin{tabular}{|c|c|c|}
\hline WSF & FFL Criteria & Justification \\
\hline \multirow[t]{3}{*}{$(5 a)$} & $\begin{array}{l}\text { ENV-21: The Operation does not engage in destruction or conversion of other valuable natural or } \\
\text { semi-natural ecosystems (see guidance) OR has taken sufficient compensatory ecosystem } \\
\text { conservation action. Any destruction or conversion in the preceding } 5 \text { years before the } \\
\text { application must be compensated by adequate ecosystem conservation practices. }\end{array}$ & $\begin{array}{l}\text { Strongly addressed: Addresses adverse effects on the ecosystem, } \\
\text { including aquatic ecosystems }\end{array}$ \\
\hline & $\begin{array}{l}\text { ENV-23: Measures are taken to maintain or, wherever possible, increase, biodiversity (diversity } \\
\text { of habitats, flora, fauna, fungi and microorganisms) in and around the managed areas (e.g., } \\
\text { different crops, or different varieties of same crops; planting of indigenous non-target plant } \\
\text { species) }\end{array}$ & $\begin{array}{l}\text { Weakly addressed: Addresses adverse effects on the ecosystem; not } \\
\text { specific to water }\end{array}$ \\
\hline & $\begin{array}{l}\text { LOC-2: There are no unresolved disputes related to the commercial use of biodiversity and } \\
\text { traditional knowledge OR all such disputes have been resolved in a transparent and mutually } \\
\text { beneficial way, based upon written agreements including prior informed consent and mutually } \\
\text { agreed terms. }\end{array}$ & $\begin{array}{l}\text { Weakly addressed: Addresses adverse effects on the ecosystem; not } \\
\text { specific to water }\end{array}$ \\
\hline (6a) & & Not addressed \\
\hline WSF & FLO Criteria & Justification \\
\hline \multirow{6}{*}{$\begin{array}{l}. \bar{\pi} \\
0 \\
\infty\end{array}$} & $\begin{array}{l}\text { 3.1.5 If you are a 2nd or 3rd grade organization, you must implement an Internal Control System } \\
\text { (ICS) on the 2nd/3rd grade level which enables you to control compliance with Fairtrade } \\
\text { requirements on all levels of the organization. }\end{array}$ & Weakly addressed: Training the people responsible; not specific to water \\
\hline & $\begin{array}{l}\text { 3.2.22 You must provide training to the members of your organization on the appropriate use of } \\
\text { fertilizers. }\end{array}$ & $\begin{array}{l}\text { Strongly addressed: Addresses training to minimize risk of water } \\
\text { pollution }\end{array}$ \\
\hline & $\begin{array}{l}\text { 3.2.26 You must provide training to the members of your organization on measures to use water } \\
\text { efficiently. }\end{array}$ & Strongly addressed: Addresses training on water efficiency \\
\hline & $\begin{array}{l}\text { 3.2.28 You must provide training to your members about waste water and the health risks it } \\
\text { bears as well as on the prevention of risks and treatment methods of waste water and their } \\
\text { implementation }\end{array}$ & Strongly addressed: Addresses training on wastewater \\
\hline & $\begin{array}{l}\text { 3.1.1 You must inform and explain to your members the environmental and labour requirements } \\
\text { in the Production chapter. }\end{array}$ & $\begin{array}{l}\text { Strongly addressed: Addresses awareness raising for all production } \\
\text { requirements (incl. water requirements) }\end{array}$ \\
\hline & $\begin{array}{l}\text { 3.1.2 You must identify which requirements in the Production chapter you and your members } \\
\text { may be at risk of not complying with. }\end{array}$ & $\begin{array}{l}\text { Strongly addressed: Addressed information from stakeholders: Relies on } \\
\text { community knowledge, member experiences and General Assembly } \\
\text { discussions }\end{array}$ \\
\hline (1b) & $\begin{array}{l}\text { 3.2.25 You must keep informed about the situation of the water sources in your area. In case local } \\
\text { environmental authorities or other entities consider that your water sources are being depleted, } \\
\text { or are in a critical situation, or under excessive pressure, you must engage in a dialogue with the } \\
\text { authorities or local existing initiatives in order to identify possible ways to be involved in } \\
\text { research or solution finding. }\end{array}$ & Strongly addressed: Addresses monitoring existing knowledge \\
\hline
\end{tabular}


Table A6. Cont.

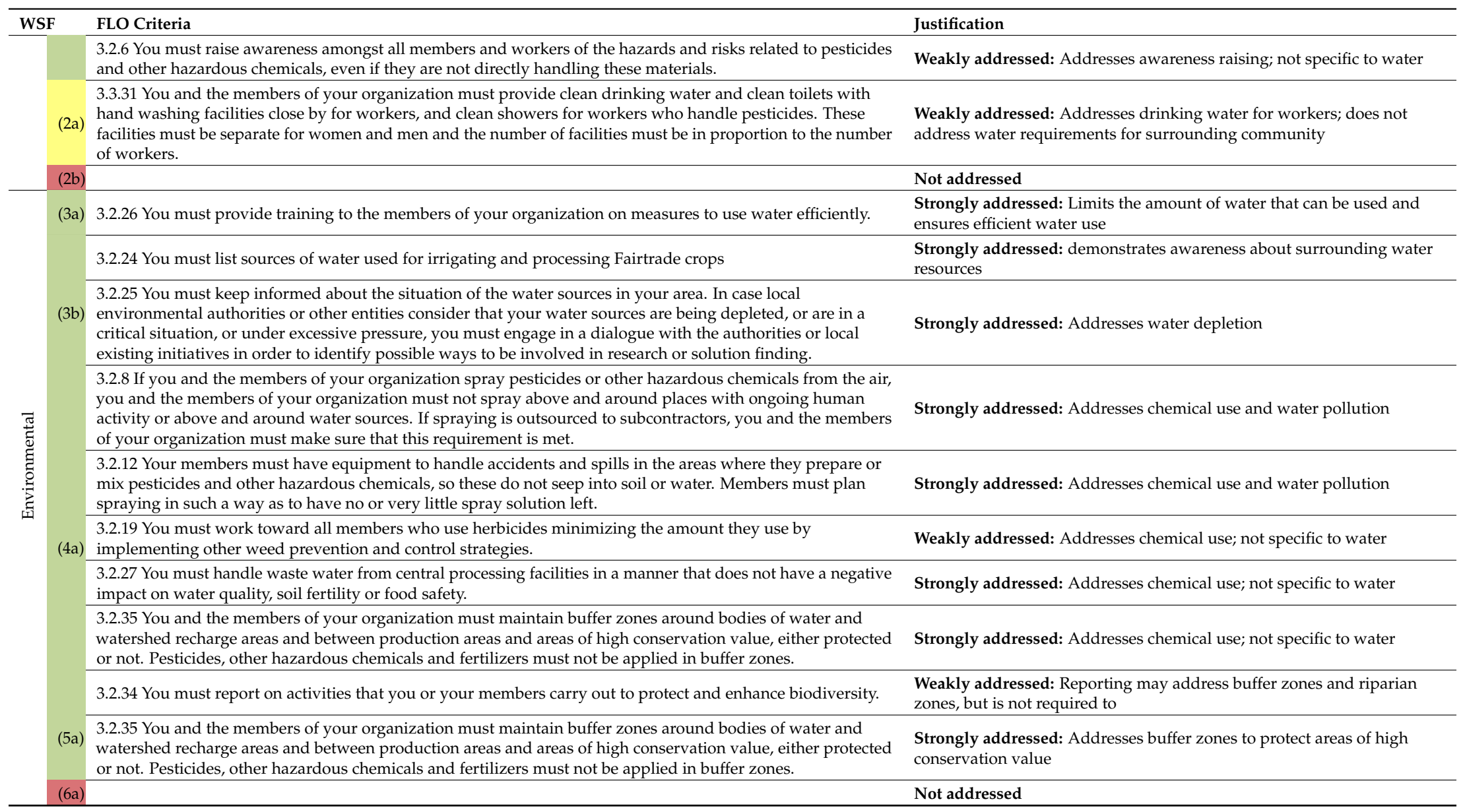


Table A7. Naturland.

\begin{tabular}{|c|c|c|c|}
\hline \multicolumn{2}{|c|}{ WSF } & Naturland Criteria & Justification \\
\hline \multirow{5}{*}{ 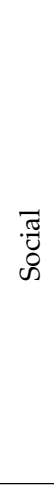 } & \multirow[t]{2}{*}{ (1a) } & $\begin{array}{l}\text { SR-6: Health and Safety-The employer is responsible for safety, health and hygiene at the } \\
\text { workplace. If necessary, this implies holding training courses for employees to raise their } \\
\text { awareness of any dangers at their workplace and of the contents of hygiene standards. } \\
\text { Operations with more than } 10 \text { workers have to draw up a policy on safety at work and make } \\
\text { these available to all employees. }\end{array}$ & Weakly addressed: Addresses training; not specific to water \\
\hline & & $\begin{array}{l}\text { SR-7.7: Further Education-The unit offers its employees the possibility of further education and } \\
\text { professional training. }\end{array}$ & Weakly addressed: Addresses training; not specific to water \\
\hline & (1b) & & Not addressed \\
\hline & $(2 \mathrm{a})$ & $\begin{array}{l}\text { SR-6: Health and Safety—All workers, employees and their families shall have access to } \\
\text { drinking water, food, accommodation and basic medical care }\end{array}$ & $\begin{array}{l}\text { Weakly addressed: Addresses access to drinking water for workers but } \\
\text { not surrounding community }\end{array}$ \\
\hline & $(2 b)$ & $\begin{array}{l}\text { SR-1: Human rights-A product created under conditions violating basic human rights, under } \\
\text { gross violation of social justice or infringing indigenous land and water rights can not be traded } \\
\text { as a product certified by Naturland. }\end{array}$ & Strongly addressed: Addresses land tenure and water rights \\
\hline \multirow{5}{*}{ 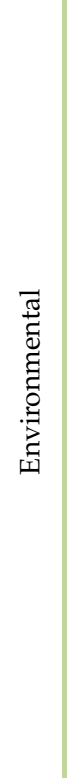 } & \multirow[b]{5}{*}{ (3a) } & $\begin{array}{l}\text { GMR-1: Sustainable Management-Natural water resources are to be used careful and in a } \\
\text { sustainable manner }\end{array}$ & Strongly addressed: Addresses sustainable use of water \\
\hline & & $\begin{array}{l}\text { PP-7.1: General-Wherever possible, rainwater is collected and used and the effects of the } \\
\text { amount of water removed from water sources monitored ... Irrigation must be in accordance } \\
\text { with good farming practice. }\end{array}$ & Strongly addressed: Address keeping water use in line with renewal rate \\
\hline & & $\begin{array}{l}\text { PP-7.2.1: General-Only efficient, water-saving irrigation systems may be used (e.g., drip, centre } \\
\text { pivot or mini sprinkler irrigation systems). Water losses must be avoided by means of regular } \\
\text { maintenance. Maintenance plans and records of maintenance must be presented. }\end{array}$ & $\begin{array}{l}\text { Weakly addressed: Addresses water use and efficiency; only in areas with } \\
\text { scarce water resources }\end{array}$ \\
\hline & & $\begin{array}{l}\text { PP-7.2.2: Water Management Plan-Farms draw up a water management plan17, which } \\
\text { comprises records and analysis of consumption, analysis of possible risks in conjunction with } \\
\text { water use and a plan of action for the reduction or prevention of these risks. }\end{array}$ & $\begin{array}{l}\text { Weakly addressed: Addresses water use; only in areas with scarce water } \\
\text { resources }\end{array}$ \\
\hline & & $\begin{array}{l}\text { PP-7.2.3: Specific Management Conditions-When consulting experts, the specific problems and } \\
\text { challenges of a catchment area, including any beyond the borders of an individual farm, are to be } \\
\text { taken into account, especially } \\
\text { - the water balance of the catchment area, } \\
\text { - assessment of the water risks of the catchment area (physical, regulatory and reputational } \\
\text { risks), } \\
\text { - sustainability of water abstraction (reasonable quantities, critical level; short, medium and } \\
\text { long term), } \\
\text { measures designed to reduce water risks, to establish sustainable water management and to } \\
\text { protect eco-systems }\end{array}$ & $\begin{array}{l}\text { Weakly addressed: Addresses water use; only in areas with scarce water } \\
\text { resources }\end{array}$ \\
\hline
\end{tabular}


Table A7. Cont.

\begin{tabular}{|c|c|c|}
\hline WSF & Naturland Criteria & Justification \\
\hline & $\begin{array}{l}\text { GMR-1: Sustainable Management-Natural water resources are to be used careful and in a } \\
\text { sustainable manner }\end{array}$ & Strongly addressed: Addresses sustainable water use \\
\hline & $\begin{array}{l}\text { PP-7.1: General-Excessive exploitation and exhaustion of water resources is not allowed. } \\
\text { Wherever possible, rainwater is collected and used and the effects of the amount of water } \\
\text { removed from water sources monitored... Irrigation must be in accordance with good farming } \\
\text { practice. }\end{array}$ & Strongly addressed: Prevents water depletion \\
\hline & $\begin{array}{l}\text { PP-7.2.2: Water Management Plan-Farms draw up a water management plan17, which } \\
\text { comprises records and analysis of consumption, analysis of possible risks in conjunction with } \\
\text { water use and a plan of action for the reduction or prevention of these risks. }\end{array}$ & $\begin{array}{l}\text { Weakly addressed: Demonstrates awareness; only in areas with scarce } \\
\text { water resources }\end{array}$ \\
\hline \multirow[t]{2}{*}{ (4a) } & $\begin{array}{l}\text { PP-1: Humus management and fertilization-Nutrient losses during storage and the application } \\
\text { of liquid fertilizers and dung as well as in irrigation have to be reduced to a minimum. The } \\
\text { quality of the ground water and surface water may not be negatively affected. }\end{array}$ & Strongly addressed: Addresses chemical use and water pollution \\
\hline & $\begin{array}{l}\text { PP-6: Landscape management-Because cultivation and animal husbandry are appropriate to } \\
\text { local conditions, organic farming methods are especially suitable for use in sensitive areas (e.g., } \\
\text { protected water conservation areas). By creating extensive bands of grassland as buffer zones } \\
\text { alongside unstable ecological systems (e.g., rivers and lakes), precautions are taken against } \\
\text { potential soil loss and nutrient input. }\end{array}$ & Strongly addressed: Addresses chemical use and water pollution \\
\hline
\end{tabular}


Table A7. Cont.

\begin{tabular}{|c|c|c|}
\hline WSF & Naturland Criteria & Justification \\
\hline \multirow[t]{2}{*}{ (5a) } & $\begin{array}{l}\text { GMR-1: Sustainable Management-The benefits derived from natural ecosystems and their } \\
\text { economic performance must be maintained.Damage to ecosystems should be kept to a minimum. } \\
\text { Biodiversity is to be maintained and fostered on farms to the best of the farmer's ability }\end{array}$ & Weakly addressed: Addresses biodiversity; not specific to water \\
\hline & $\begin{array}{l}\text { PP-7.2.3: Specific Management Conditions-When consulting experts, the specific problems and } \\
\text { challenges of a catchment area, including any beyond the borders of an individual farm, are to be } \\
\text { taken into account, especially } \\
\text { - the water balance of the catchment area, } \\
\text { - assessment of the water risks of the catchment area (physical, regulatory and reputational } \\
\text { risks), } \\
\text { sustainability of water abstraction (reasonable quantities, critical level; short, medium and } \\
\text { long term), } \\
\text { measures designed to reduce water risks, to establish sustainable water management and to } \\
\text { protect eco-systems }\end{array}$ & $\begin{array}{l}\text { Weakly addressed: Addresses biodiversity; only in areas with scarce } \\
\text { water resources }\end{array}$ \\
\hline \multirow{2}{*}{ (6a) } & $\begin{array}{l}\text { PP-7.2.4: Use of Non-renewable water sources-The use of non-renewable (fossil) water } \\
\text { resources for agricultural production is only possible if consultation with experts has furnished } \\
\text { credible proof that this use does not conceal any significant ecological or social risks. In this case, } \\
\text { the analysis must cover the whole catchment area as well as any possible social and ecological } \\
\text { consequences for other parts of the country or in other countries. Both short and long term risks } \\
\text { are to be assessed. The results are to be presented to Naturland prior to (possible) certification. }\end{array}$ & $\begin{array}{l}\text { Weakly addressed: Addresses biodiversity; only in areas with scarce } \\
\text { water resources }\end{array}$ \\
\hline & $\begin{array}{l}\text { PP-7.2.3: Specific Management Conditions-When consulting experts, the specific problems and } \\
\text { challenges of a catchment area, including any beyond the borders of an individual farm, are to be } \\
\text { taken into account, especially } \\
\text { - the water balance of the catchment area, } \\
\text { - assessment of the water risks of the catchment area (physical, regulatory and reputational } \\
\text { risks), } \\
\text { sustainability of water abstraction (reasonable quantities, critical level; short, medium and } \\
\text { long term), } \\
\text { measures designed to reduce water risks, to establish sustainable water management and to } \\
\text { protect eco-systems }\end{array}$ & $\begin{array}{l}\text { Weakly addressed: Addresses water scarcity; only in areas with scarce } \\
\text { water resources }\end{array}$ \\
\hline
\end{tabular}




\section{References}

1. FAO; ICAC. Measuring Sustainability in Cotton Farming Systems. Available online: https://www.icac.org/ getattachment/Home-International-Cotton-Advisory-Committee-ICAC/measuring-sustainability-cottonfarming-full-english.pdf (accessed on 23 November 2017).

2. Armedangels. Advertisement. Available online: https://mobil.deutschebahn.com/system/magazines/ files/000/000/030/original/DB_MOBIL_082017.pdf?1500473925 (accessed on 30 November 2017).

3. Armedangels. Join the fashion revolution: Video. Available online: https: $/ /$ www.youtube.com $/$ watch? $\mathrm{v}=$ 9tMrRN_BtuA (accessed on 30 November 2017).

4. Bartley, T. Institutional emergence in an era of globalization: The rise of transnational private regulation of labor and environmental conditions. Am. J. Sociol. 2007, 113, 297. [CrossRef]

5. Kingdon, J.W. Agenda, Alternatives, and Public Policies; Harper Collins: New York, NY, USA, 1984.

6. Lernoud, J.; Jason, P.; Sampson, G.; Garibay, S.; Lynch, M.; Voora, V.; Willer, H.; Wozniak, J. The State of Sustainable Markets: Statistics and emerging trends 2017; ITC: Geneva, Switzerland, 2017; ISBN 9789291374502.

7. Fuchs, D. Business power in global governance; Lynne Rienner Publishers, Inc.: Boulder, CO, USA, 2007.

8. Green, J.F. Rethinking private authority: Agents and entrepreneurs in global environmental governance; rinceton University Press: Princeton, NY, USA, 2013.

9. BSD Consulting. Get Changed Homepage: Get Changed hat gemeinsam mit BSD Consulting $2013 \mathrm{im}$ Auftrag der AK Oberösterreich neun Textilsiegel analysiert. Available online: https: / www.getchanged.net/ magazin.asp?kategorie=nachhaltigkeitsstandards (accessed on 20 November 2017).

10. CIR Ein Wegweise durch das Label-Labyrinth; Christliche Initiative Romero: Münster, Germany, 2017.

11. Kemper, L.; Partzsch, L. A water sustainability framework for assessing biofuel certification schemes: Does European hybrid governance ensure sustainability of palm oil from Indonesia? J. Clean. Prod. 2018, 26, 835-843. [CrossRef]

12. Raynolds, L.T.; Murray, D.; Heller, A. Regulating sustainability in the coffee sector: A comparative analysis of third-party environmental and social certification initiatives. Agric. Human Values 2007, 24, 147-163. [CrossRef]

13. Bachrach, P.; Baratz, M.S. Two faces of power. Am. Polit. Sci. Rev. 1962, 4, 947-952. [CrossRef]

14. Conca, K. Governing water: Contentious transnational politics and global institution building; The MIT Press: Cambridge, MA, USA, 2006.

15. Simonis, U.E. Die Reform der Umweltpolitik der Vereinten Nationen. In Die Reform der Vereinten Nationen: Bilanz und Perspektiven; Varwick, J., Zimmermann, A., Eds.; Duncker \& Humblot: Berlin, Germany, 2006; pp. 229-241.

16. Haufler, V. Disclosure as Governance: The Extractive Industries Transparency Initiative and Resource Management in the Developing World. Glob. Environ. Polit. 2010, 10, 53-73. [CrossRef]

17. Koenig-Archibugi, M.; Macdonald, K. Accountability-by-proxi in transnational non-state governance. Gov. An Int. J. Policy, Adm. Institutions 2013, 26, 499-522. [CrossRef]

18. Strange, S. The Retreat of the State. The Diffusion of Power in the World Economy; Cambridge University Press: Cambridge, MA, USA, 1997.

19. Dingwerth, K.; Pattberg, P. World politics and organizational fields: the case of transnational sustainability governance. Eur. J. Int. Relations 2009, 15, 707-743. [CrossRef]

20. Hoskins, T.E. Stiched Up: The Anti-Capitalist Book of Fashion; Pluto Press: London, UK, 2014.

21. Sneyd, A. When Governance Gets Going: Certifying "Better Cotton" and "Better Sugarcane". Dev. Change 2014, 45, 231-256. [CrossRef]

22. Partzsch, L. The legitimacy of biofuel certification. Agric. Human Values 2011, 28, 413-425. [CrossRef]

23. Brooks, A. Clothing Poverty: The Hidden World of Fast Fashion and Second-Hand Clothing; Zed Books: London, UK, 2015.

24. Quark, A. Global Rivalries: Standards Wars and the Transnational Cotton Trade; University of Chicago Press: Chicago, IL, USA, 2013.

25. Çalişkan, K. Market Threads: How Cotton Farmers and Traders Create a Global Commodity; Princeton University Press: Princeton, NY, USA, 2010.

26. Sneyd, A. Governing Cotton: Globalization and Poverty in Africa; Palgrave Macmillan: Basingstoke, UK, 2011. 
27. OECD; FAO. OECD-FAO Agricultural Outlook 2016-2025: Special Focus: Sub-Saharan Africa. Available online: http:/ / dx.doi.org/10.1787/agr_outlook-2016-en (accessed on 4 July 2018).

28. OECD; FAO. World Fertilizer Trends and Outlook to 2020: Summary Report. Available online: http: / /www.fao.org/3/a-i6895e.pdf (accessed on 5 July 2018).

29. IUCN. Homepage: Water pollution. Available online: www.iucnredlist.org/initiatives/freshwater/ panafrica/threats (accessed on 30 July 2018).

30. UNICEF. Progress on drinking water, sanitation and hygiene: Update and SDG baselines. Available online: https: / / data.unicef.org/wp-content/uploads/2017/07/JMP-2017-report-launch-version_0.pdf (accessed on 30 July 2018).

31. Benson, D.; Huitema, D.; Jordan, A. Involving the public in catchment management: An analysis of the scope for learning lessons from abroad. Environ. Policy Gov. 2012, 22, 42-54. [CrossRef]

32. Newig, J.; Kochskämper, E.; Challies, E.; Jager, N.W. Exploring governance learning: How policymakers draw on evidence, experience and intuition in designing participatory flood risk planning. Environ. Sci. Policy 2016, 55, 353-360. [CrossRef] [PubMed]

33. Brühl, T.; Debiel, T.; Hamm, B.; Hummel, H.; Martens, J. Die Privatisierung der Weltpolitik: Entstaatlichung und Kommerzialisierung im Globalisierungsprozess; Dietz: Bonn, Germany, 2001.

34. Baumgartner, F.R.; Jones, B.D. Agendas and Instability in American Politics; University of Chicago Press: Chicago, IL, USA, 1993.

35. Moore, M.L.; Westley, F.; Tjornbo, O.; Holroyd, C. The Loop, the lens, and the lesson: Using resilience theory to examine public policy and social innovation. In Social Innovation; Nicholls, A., Murdock, A., Eds.; Palgrave Macmillan: Basingstoke, UK, 2012.

36. Pekdemir, C. On the regulatory potential of regional organic standards: Towards harmonization, equivalence, and trade? Glob. Environ. Chang. 2018, 50, 289-302. [CrossRef]

37. Barratt Brown, M. "Fair Trade" with Africa. Rev. Afr. Polit. Econ. 2007, 34, 267-277. [CrossRef]

38. Naturland. Naturland Standards on Production. Available online: https://www.naturland.de/en/285naturland-uk/naturland/naturland-standards/standards-producers/854-production.html (accessed on 20 October 2017).

39. Naturland. Öko-Textilien haben Stil: Brochure. Available online: https://naturland.de/images/Naturland/ Publikationen/allgemein/PDFs/Textil_Broschuere_02_2007.pdf (accessed on 30 November 2017).

40. Cashore, B.W.; Auld, G.; Newsom, D. Governing through Markets: Forest Certification and the Emergence of Non-State Authority; Yale University Press: New Haven, CT, USA, 2004.

41. Amera, T. Cotton Farmers do Better with IPM in Arba Minch, Ethiopia. Available online: ttp:/ / afsafrica. org/wp-content/uploads/2016/02/IPM-in-Arba-Minch-Ethiopia.pdf (accessed on 27 June 2017).

42. PAN UK. Homepage: Pesticides Action Network. Available online: www.pan-uk.org/pesticide-free-cotton/ (accessed on 1 October 2017).

43. Textile Exchange. Homepage. Available online: http://textileexchange.org/about-us/ (accessed on 30 July 2017).

44. Macdonald, K. Globalising justice within coffee supply chains? Fair Trade, Starbucks and the transformation of supply chain governance. Third World Q. 2007, 28, 793-812. [CrossRef]

45. FLO. Scope and Impact of Fairtrade. Available online: www.fairtrade.net/fileadmin/user_upload/content/ 2009/resources/2015-Monitoring_and_Impact_Report_web.pdf (accessed on 30 November 2017).

46. Armedangels. Homepage: Armedangels. Available online: https://www.armedangels.de/ (accessed on 27 November 2017).

47. FFL. Homepage: Fair for Life. Available online: http://www.fairforlife.org/pmws/indexDOM.php?client_ id=fairforlife\&page_id=home (accessed on 7 November 2017).

48. BCI. Homepage: Better Cotton Initiative. Available online: http://bettercotton.org/ (accessed on 10 May 2018).

49. CmiA. Homepage: Cotton Made in Africa. Available online: http://www.cottonmadeinafrica.org/en/ about-us/the-initiative (accessed on 15 May 2017).

50. Juwana, I.; Muttil, N.; Perera, B.J.C. Indicator-based water sustainability assessment-A review. Sci. Total Environ. 2012, 438, 357-371. [CrossRef]

51. Loucks, D.P. Sustainable Water Resources Management. Int. Water Resour. Assoc. 2000, 25, 3-10. [CrossRef] 
52. UN Water. Water for a Sustainable World. Available online: http://www.unesco.org/new/en/ natural-sciences/environment/water/wwap/wwdr/2015-water-for-a-sustainable-world/ (accessed on 10 April 2017).

53. UN Water. A Post-2015 Global Goal for Water. Available online: http:/ / www.un.org/waterforlifedecade/ pdf/27_01_2014_un-water_paper_on_a_post2015_global_goal_for_water.pdf (accessed on 10 April 2017).

54. Juwana, I.; Perera, B.J.C.; Muttil, N. A water sustainability index for West Java. Part 1: Developing the conceptual framework. Water Sci. Technol. 2010, 62, 1629-1640. [CrossRef]

55. Sullivan, C. Calculating a Water Poverty Index. World Dev. 2002, 30, 1195-1210. [CrossRef]

56. Gleick, P.H. Water in crisis: Paths to sustainable water use. Ecol. Appl. 1998, 8, 571-579. [CrossRef]

57. Bossio, D.; Mccartney, M. Water Implications of Foreign Direct Investment in Ethiopia' s Agricultural Sector. Water Alternatives 2012, 5, 223-242.

58. Sima, S.; Restiani, P. Water Governance Mapping Report: Textile Industry Water Use in Ethiopia. Available online: http:/ / www.siwi.org/wp-content/uploads/2017/06/Water-Governance-Mapping-Report-Ethiopia.pdf (accessed on 10 April 2017).

59. Diaz-Chavez, R.; Kunen, E.; Walden, D.; Fingerman, K.; Arya, L.; Chalmers, J.; Kretschmer, B.; Poláková, J.; Farmer, A.; Bowyer, C.; et al. Mandatory Requirements in Relation to Air, Soil, or Water Protection: Analysis of Need and Feasibility. Available online: https:/ / ec.europa.eu/energy/sites/ener/files/documents/2013_ tasks3and4_requirements_soil_air_water.pdf (accessed on 10 April 2017).

60. Flint, R.W. The Sustainable Development of Water Resources. Water Resour. Updat. 2004, 127, 41-51.

61. UN Water. Water-Related Hazards. Available online: http://www.unwater.org/topics/water-relatedhazards/en/ (accessed on 26 January 2017).

62. UNESCO. National Water Development Report for Ethiopia. Available online: http://unesdoc.unesco.org/ images/0014/001459/145926e.pdf (accessed on 17 November 2017).

63. Fairtrade International. Fairtrade Standard for Small Producer Organizations. Available online: https: / / www.fairtrade.net/standards/our-standards.html (accessed on 20 January 2018).

64. CmiA. Cotton Made in Africa (CmiA) Criteria Matrix. Available online: https:/ / www.cottonmadeinafrica. org/en/materials/cmia-standard/cmia-standards-documents (accessed on 7 November 2017).

65. FFL. Fair for Life Certification Standard for Fair Trade and Responsible Supply-Chains. Available online: http:/ / www.fairforlife.org/pmws/indexDOM.php?client_id=fairforlife\&page_id=root_2_3\&lang iso639=en (accessed on 20 October 2017).

66. BCI. Better Cotton Production Principles and Criteria Explained. Available online: https://bettercotton. org/about-better-cotton/better-cotton-standard-system/production-principles-and-criteria/ (accessed on 7 November 2017).

67. Armedangels. Behind the Fields: Why We Use Organic Fairtrade Cotton. Available online: https://www. youtube.com/watch?v=w-1pRiFnCWA (accessed on 30 July 2018). 